\title{
AVLIS \\ Production Plant \\ Preliminary Quality Assurance \\ Plan and Assessment
}

Document APP-045

November 15, 1984

Reviewed by
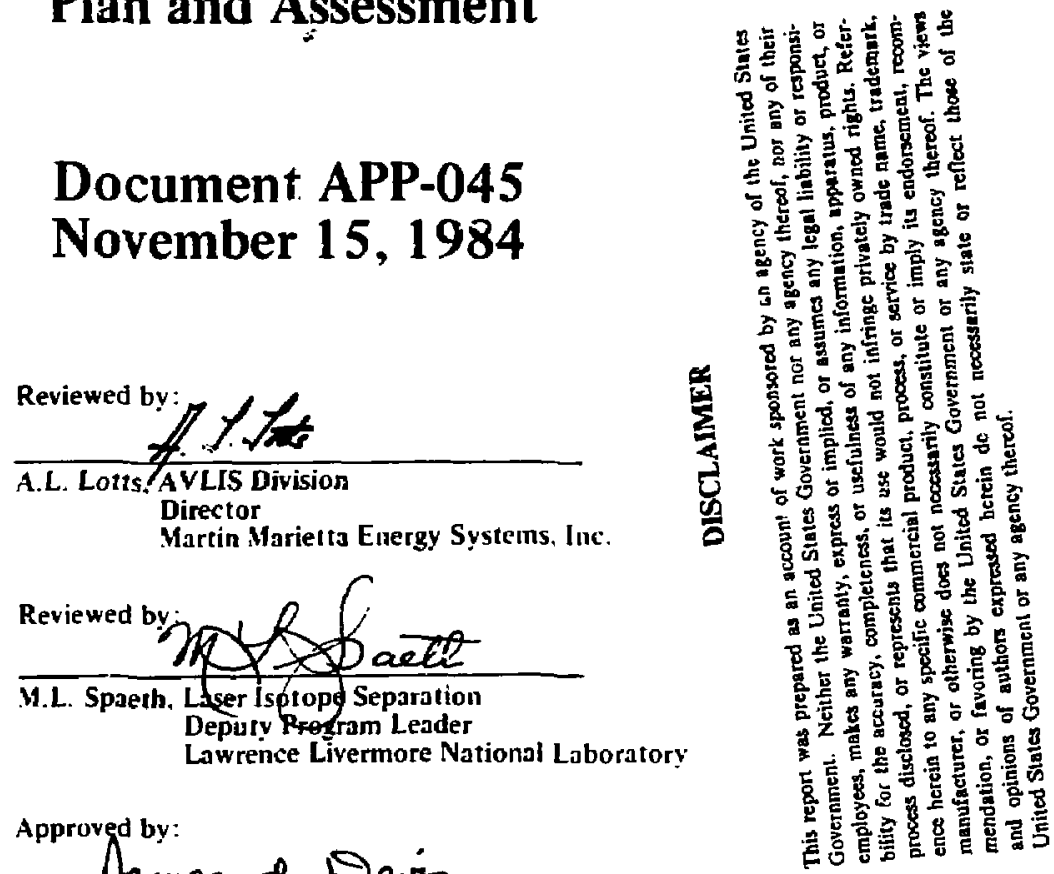

Approved by:
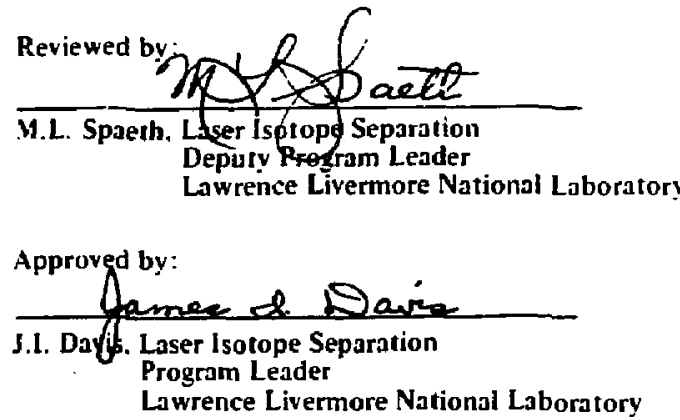

LAWRENCE LIVERMORE NATIONAL LABORATORY University of California - Livermore, California - 94550

MARTIN MARIETTA ENERGY SYSTEMS, INC. MARTI MAREETA

Oak Ridge, Tennessee, 37831

mane:

Friwuns of tais Repont aAE rLLEGIBLE.

II has bann reproduced from the best avallable cent to gormit the broadest pesetab wavality. 


\section{AVLIS \\ Production Plant \\ Preliminary Quality Assurance \\ Plan and Assessment}

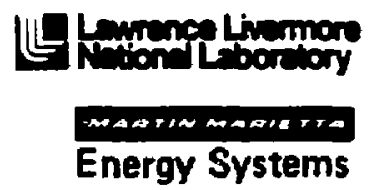

Prepared by the AVLIS Program at Lawrence Livermore National Laboratory and Martin Marietta Energy Systems, Inc., with major contributions from Bectel National, Inc.

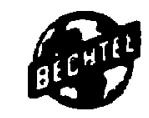

Bechtel National

Incorporated 
List of Figures . . . . . - . . . . . . . . . . . . . v

List of Tables

1. Executive Sumary . . . . . . . . . . . . . . . 1

1.1. Introduction . . . . . . . . . . . . . . . 1

1.2. Scope . . . . . . . . . . . . . . . . . 2

1.3. Objective . . . . . . . . . . . . . . . . 2

1.4. Quality Assurance Program . . . . . . . . . . . 3

1.5. Organization . . . . . . . . . . . . . . . 4

1.5. Quality Assurance Action Elements . . . . . . . . . 4

1.7. Risk Assessments . . . . . . . . . . . . . . . s

1.8. Program Implementation and Control . . . . . . . . . 6

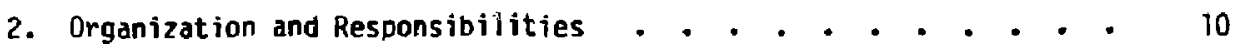

3. Quality Assurance Action Elements . . . . . . . . . . 15

3.1. Design Control . . . . . . . . . . . . . . . . 15

3.2. Procurement Control . . . . . . . . . . . . . 15

3.2.1. Procurement Document Control . . . . . . . 15

3.3.2. Subcontractor Control . . . . . . . . . . . 16

3.3. Instructions, Procedures, and Drawings . . . . . . . 16

3.4. Document Control . . . . . . . . . . . . . . 16

3.5. Control of Purchased Materials,

Equipment and Services . . . . . . . . . . . 17

3.6. Identification and Control of Materials,
Parts, and Components . . . . . . . . . 17

3.7. Control of Special Processes . . . . . . . . . . 18

3.8, Inspection . . . . . . . . . . . . . . 18

3.9. Test Control . . . . . . . . . . . . . . . 18 
3.10. Control of Measuring and Test Equipment . . . . . . . 19

3.11. Handling, Storage, aná Shipping . . . . . . . . . . 19

3.12. Inspection, Test, and Operating Status . . . . . . . . 20

3.13. Control of Norconforming Items . . . . . . . . . . 20

3.14. Software Contr.l . . . . . . . . . . . . . . 20

3.15. Quality Assurance Records . . . . . . . . . . . 21

3.16. Safety Control . . . . . . . . . . . . . . 11

4. Preliminary Risk Assessnent . . . . . . . . . . . . . 22

4.1. Introduction . . . . . . . . . . . . . . . . 22

4.2. Scope . . . . . . . . . . . . . . . . 22

4.3. Methodology . . . . . . . . . . . . . . . 23

4.3.1. Consequence Level . . . . . . . . . . 25

4.3.2. Probability factor . . . . . . . . . . . . 25

4.3.3. Risk Evaluation... . . . . . . . . . . 28

4.4. Results . . . . . . . . . . . . . . . 30

5. Progran Impleaentation and control . . . . . . . . . . 48

5.1. Level of quality Assurance . . . . . . . . . . . . 48

5.2. Application of Quality Assurance
Action Elements to Design . . . . . . . . . . . 50

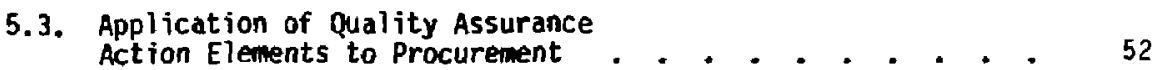

5.4. Application of Quality Assurance
Action Elements to Construction . . . . . . . . . 53

5.5. Quality Assurance Program Schedule
and Milestones. . . . . . . . . . . . . . . . . . 54

5.6. Quality Audits . . . . . . . . . . . . . 54

5.7. Quality Failure Reports . . . . . . . . . . . . 54

5.8. Quality Management Reports . . . . . . . . . . . . 54

Appendix A: Tems and Definitions . . . . . . . . . . . 58 


\section{LIST OF FIGIRES}

( Fig. 1-1. Quality Assurance Program Key Milestones . . . . . . 9

Fig. 2-1. Organization for AVLIS Production Facility Project . . - 12

Fig. 2-2. Organization for AVLIS Production Piant Project . . . . 13

Fig. 4-1. AVLIS Work Breakdown Structure . . . . . . . . . . 24

Fig. 4-2. Qualitative Assessment Procedure . . . . . . . . . 26

Fig. 4-3. Matrix for Determination of Special Action Classification... - . . . . . . . . . 29

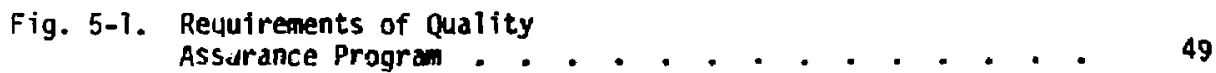

Fig. 5-2. Quality Assurance Program Milestones . . . . . . . . 57 


\section{LIST OF TABLES}

Table 1-1. Quality Assurance Program Milestenes . . . . . . . . 8

Table 4-1. Criteria for Defining Consequence of Failure . - . . - 27

Table 4-2. Preliminary Risk Assessment for Work Breakdown

Structure 1.2.1.1 Copper Laser System . . . . . . . 32

Table 4-3. Preliminary Risk Assessment for Work Breakdown

Structure 1.2.1.2 Dye Lasers . . . . . . . . . 33

Tablt 4-4. Preliminary Risk Assessment for Work Breakdown

Structure 1.2.7.3 Optical System . . . . . . . . . 34

Table 4-5. Preliminary Risk Assessment for Work Breakdown

Structure 1.2.1.5 Refurbishment and Test . . . . . . 34

Table 4-6. Preliminary Risk Assessment for Work Breakdown

Structure 1.2.2.1 Pod System . . . . . . . . . . 35

Table 4-7. Preliminary Risk Assessment for Work Breakdown

Structure 1.2.2.3 Module System . . . . . . . . . 38

Table 4-8. Preliminary Risk Assessment for Work Breakdown

Structure 1.2.2.4 Refurbishment/Test . . . . . . . 40

Table 4-9. Preliminary Risk Assessment for Hork Breakdown

Structure 1.3.1 Feed Conversion . . . . . . . . . 42

Table 4-10. Prel iminary Risk Assessment for Work Breakdown

Structure 1.3.2 Feed Preparation . . . . . . . 43

Table 4-11. Preliminary Risk Assessment for Work Breakdown

Structure 1.3.3 Product Conversion . . . . . . . . 44

Table 4-12. Prel iminary Risk Assessment for Work Breakdown

Structure 1.3.4 Uranium Recovery . . . . . . . 46

Table 4-13. Preliminary Risk Assessment for Work Breakdown

Structure 1.3.5 Process Support . . . . . . . 47

Table 5-1. Procedures Applicable to Design (Title I \& II) . . . . 51

Table 5-2. Procedures Applicable to Procurement . . . . . . 52

Table 5-3. Procedures Applicable to Construction . . . . . . . 53

Table 5-4, Quality Assurance Program Milestones . . . . . . . 56 


\section{EXECUTIVE SUMAARY}

\subsection{INTROOUCTION}

This preliminary Quality Assurance P1an and Assessment establishes the Quality Assurance requirements for the AVLIS Production Plant Project. The Quality Assurance Plan defines the management approach, organization, interfaces, and controls that will be used in order to provide adequate confidence that the AVLIS Production Plant design, procurement, construction, fabrication, installation, start-up, and operation are accomplished within established goals and objectives.

The AVLIS project is a joint effort by LLNL and Mart in Marietta Energy Systems, both having institutional quality assurance programs. To specifically address the AVLIS Production Plant needs, the two organizations have prepared this joint Quality Assurance Plan. This document establishes the joint Quality Assurance Plan requirements. The requirements contained herein are in accordance with those specified in both DOE Document OR 5700.6 "Quality Assurance - ORO Site Implementation Plan" and with DOE Document SAN MD No. 5700.6 "Quality Assurance."

The Quality Assurance Program defined in this document includes a system for assessing those elements of the project whose failure would have a significant impact on safety, environment, schedule, cost, or overall plant objectives. As elements of the project are assessed, classifications are provided to establish and assure that special actions are aefined which will eliminate or reduce the probability of occurrence or control the consequences of failure. 
All contractor organizations shall participate in the AVLIS Quality Assurance Progran in accordance with the requirements of this document either by direct application or as imposed ihrough contract requirements. The AVLIS Quality Assurance Progran applies to activities related to the establishment of design criteria and requirements for the design and development, procurement, fabrication, construction, installation and start-up phases of the project. When equipment and facilities receive final acceptance, the plant operator shall implement an operations quality assurance program consistent with DOE requirements.

Quality Assurance cost and schedule impacts on the AVLIS Production plant have been accounted for by this Quality Assurance Plan and assessment and by existing quality assurance plans at Lawrence Livermore National Laboratory and Martin Marietta Energy Systems, Inc.

\subsection{OBJECTIVE}

The objective of this program is to assure that management attention and support for quality assurance are systematically applied by all participants. In addition, the program should assure that adequate plans and actions are established, implemented and maintained with emphasis on achieving a high degree of operational success with due consideration to health and safety, environmental protection, performance, and reliability. The emphasis should be on actions necessary to prevent significant quality problems.

Each project participant shali have a program for assuring quality of services, equipment, and facilities. Concern for quality shall be visible and shall receive management attention. To maximize effectiveness, the Quality Assurance program shall be selectively applied to emphasize prevention of major problems. The program shall include provisions which assure that each employee clearly understands his/her role in providing assurance of quality.

The AVLIS quality assurance program is based on the following principles. These principles form the foundation of the quality assurance program. 
1. Preplanring is a key element for early detection and prevention of problems: During the preplanning phase, the assessment process is used to evaluate the risk of failure of equipment, facilities, or management systems. When the risk is judged to be unacceptable or unknown a quality assurance action plan is required. This plan describes the action to be taken to prevent or correct the problems. Methods used to detect or prevent quality problens include independent design reviews, vendor surveillance, first-article evaluations, inspections, document and change control, and training.

2. The line organization is responsible for the quality of their work: To achieve quality, the line organization must participate in the quality assurance program. This includes quality assurance planning, development of procedures and the implementation of these plans and procedures.

3. The operator of the facility must be involved in the quality assurance program: Organizations responsible for the operation and maintenance of the faclity must participate in and monitor quality assurance during design and construction. Potential operating problems must be identified and corrected before start-up and operation.

4. Independent evaluation wilt verify the adequacy of the quality assurance program: To enhance the effectiveness of the quality assurance program, quality assurance personnel should provide an independent evaluation of the adequacy of the quality assurance program implementation.

\subsection{QUALITY ASSURANCE PROGRAM}

A quality assurance program that complies with the requirements of this document shall be established by project participants, at the earliest practical time prior to start of activities. The program shall provide for application of control and verification activities consistent with the impartance of an item or service to safety, reliability, and performance, and shall provide for the documentation of quality related activities. The 
progran shall include a system for identifying, documenting, preventing and resolving problems before they have significant impact. The quality Assurance Program applies to activities during development, engineering, procurement, fabrication, construction, operation, and maintenance. Implementing procedures consistant with this quality program $p$ lan will be prepared by individual program participants.

\subsection{ORGANIZATION}

Each contractor organization shall define the organizational structure within which the quality Assurance Program is to be planned and implemented. The organizational description shall clearly delineate the responsibilities and authority of the various personnel and organizations involved. The person responsible for the formulation and direction of the Quality Assurance Program shall have direct access to management at a level where appropriate action can be initiated when required and shall report regularly an the effectiveness of the program. Persons and organizations performing Quality Assurance functions shall have sufficient authority and organizational freedom to verify conformance to quality requirements, detect early breakdowns in quality systems, identify and report quality probiems, and initiate, recommend or provide solutions, as appropriate, through designated channels. The AVLIS Project Organization is defined in Sec. 2. The organizational structure and interface between principal participants is described in detail in the AVLIS Production Plant Project Management Plan (APPOTD).

\subsection{QUALITY ASSURANCE ACTION ELEMENTS}

This section lists commonly referenced quality assurance action elements. These elements are frequently used in the management of project activities, and it is necessary for all project participants to have a common understanding of these elements. The selective application of these elements in Quality Assurance Action Plans is determined by the concerns identified in the project risk assessments. The application of these elements is not limited by the Risk Assessment and Quality Assurance Action PIan. Elements 
may he applied at the discretion of management when considered necessary for control of project activities. Application of Quality Assurance action elements is further defined in Secs. 3 and 5 .

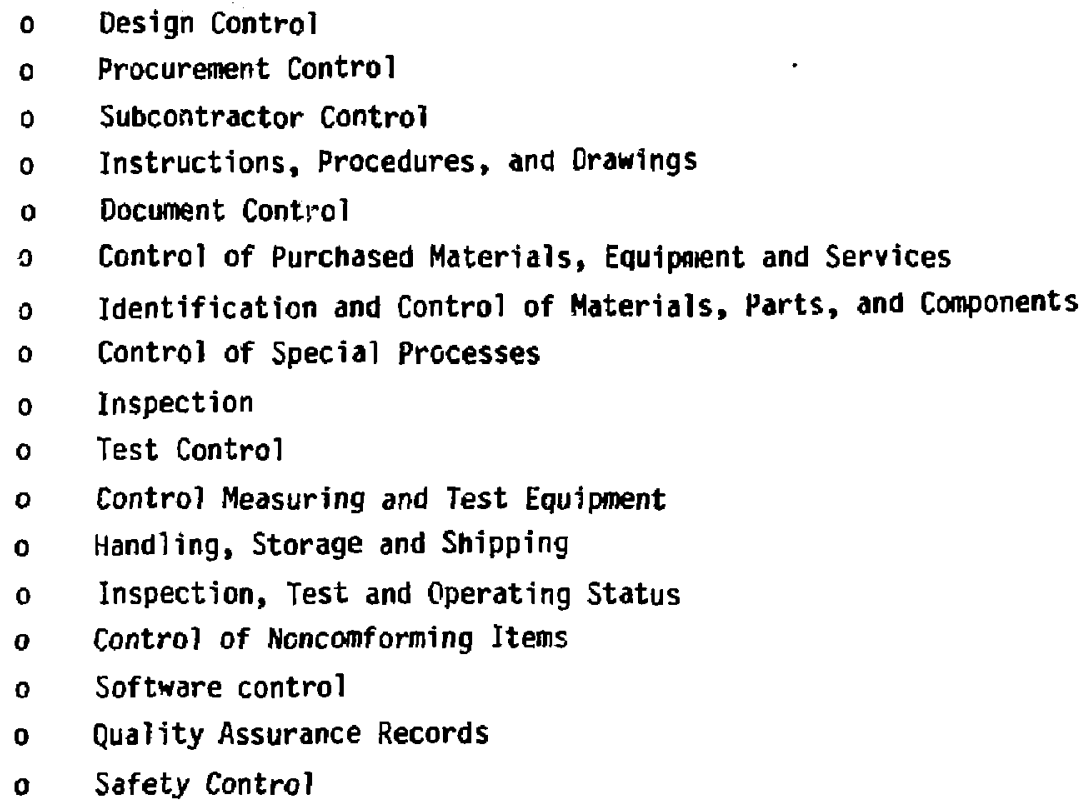

\subsection{RISK ASSESSMENTS}

Risk assessments shall be conducted during the Title I phase of the project with the intent of identifying those elements of the project where significant adverse impact would be experienced if that system, service, facility, or component, etc., did not perform satisfactorily. In determining adverse impact, consideration shall be given to risk which includes the consequences of failure and the probability of failure. The project elements to be formally evaluated shall include any managenent practice, functional design, equipment selection, organizational infrastructure, environmental factor, safety factor, program goal, cost constraints, program schedules, etc., which would impact the achievement of operational success. Accordingly, items requiring special actions will be identified. 
The assessment process is progressive, and iterative. Project assessments shall begin at the management systens level focusing on those project elements necessary to manage the AVLIS project. Subsequent assessments will focus on a further breakdown of the lower levels of the Hork Breakdwon Structure and will utilize design details which become available as the design progresses. The entire risk assessment process is iterative in that project element risk may be reevaluated any time sufficient change has occurred to warrant an assessment.

Risk assessments shall be initiated as early as feasible in the design. This permits the early identification of project elements requiring additional management attention.

The organization responsible for performing a risk assessment shall assure all project phases are addressed and that representatives from various appropriate disciplines participate in the assessment. The operator or user of the facility must participate in the assessment process. A preliminary risk assessment has been completed and details are in Sec. 4. This assessment has identified several systems and components require quality assurance actions beyond the existing lever of assurance.

\subsection{PROGRAM IMPLEMENTATION AND CONTROL}

When results of the Assessments identify items requiring special actions, quality Assurance Action Plans shall be prepared by the responsible design organization to establish actions to elimirate or reduce the probability of occurrence, or to control the consequences of failure. Quality Assurance Action Plans shall be initiated as soon as the necessity for one becomes evident. Preparation and review of Quality Assurance Action Plans should involve all disciplines necessary to cover the broad range of actions required during all phases of the project including design, procurement, fabrication, construction, start up, and operations. Actions to be considered in the rireparation of Quality Assurance Action Plans are defined in Sec. 3.

When $z$ Risk Assessment has established that an item requires no special actions, a Quality Assurance Action Plan is not required; however, participants are required to take appropriate steps to identify and preyent 
quality problems in their areas of responsibility. Mationally recognized codes and standards shall be invoked in specifications and drawings as applicable. Each participant's standard practices and procedures may also be acceptable. In the event that significant quality problems occur, formal investigations shall be performed to identify deficiencies and immediate corrective action initiateu. Quality Assurance Program implementation is defined in Sec. 5.

The Quality Assurance Program is initiated for the AVLIS Production Plant Project upon fivLIS process selection and continues through Title I, II, and III, and start-up phases of the project. The major milestones for the Quality Assurance Program are listed in Table 1-1. The timing of Quality Assurance Key Milestones relative to the Authorization Limited Schedule is shown in Fig. 1-1.

Control of project quality activities shall be accomplished through a system of planned and scheduled audits conducted by teams defined by the detailed Quality Assurance plans, including quality Assurance personnel. Reports of audits sha1l be issued identifying deficiencies and recomended corrective actions. Management shall be kept informed of the status and effectiveness of the Quality Assurance program. 
Table 1-1. Quality Assurance Program Milestones.

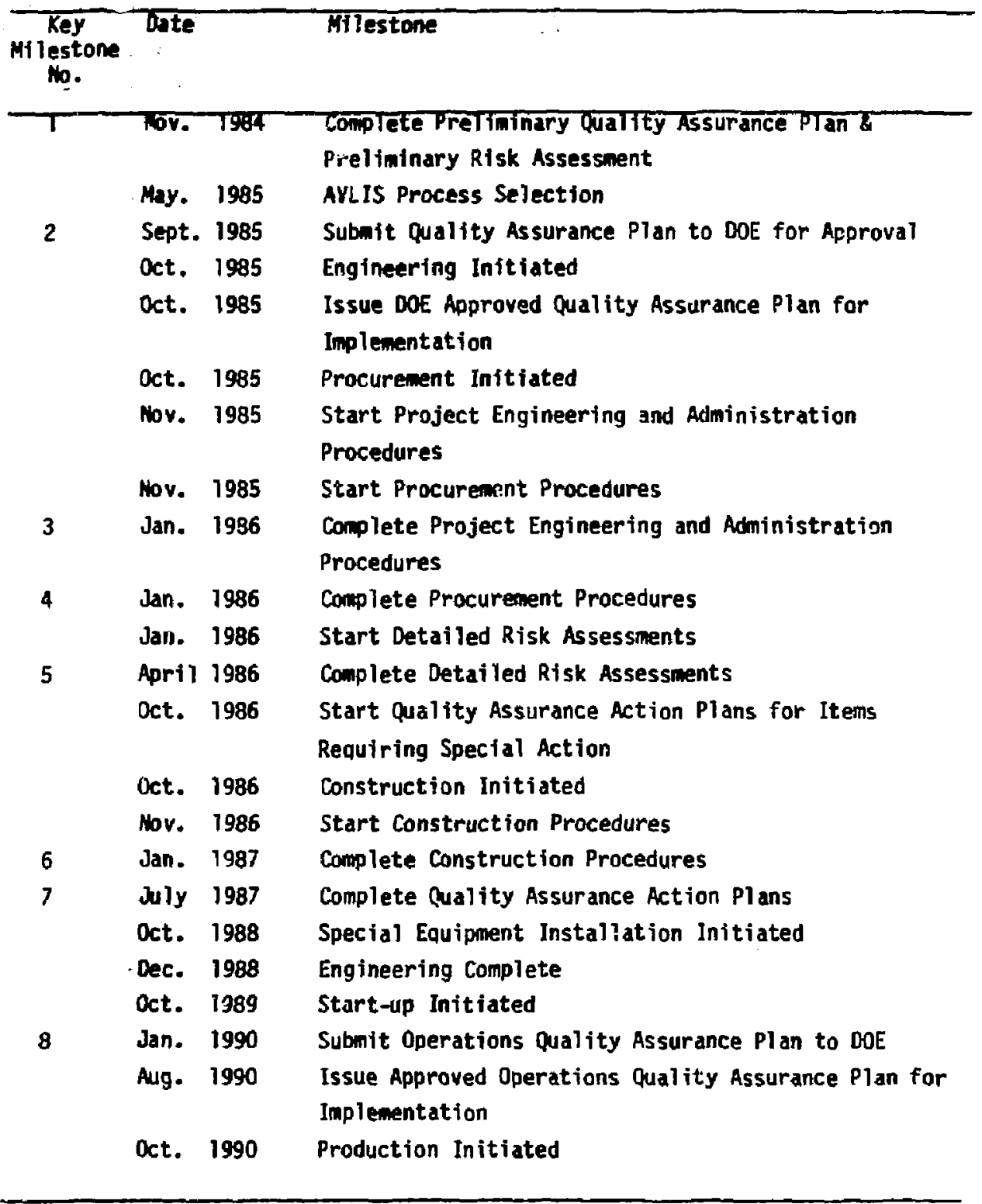




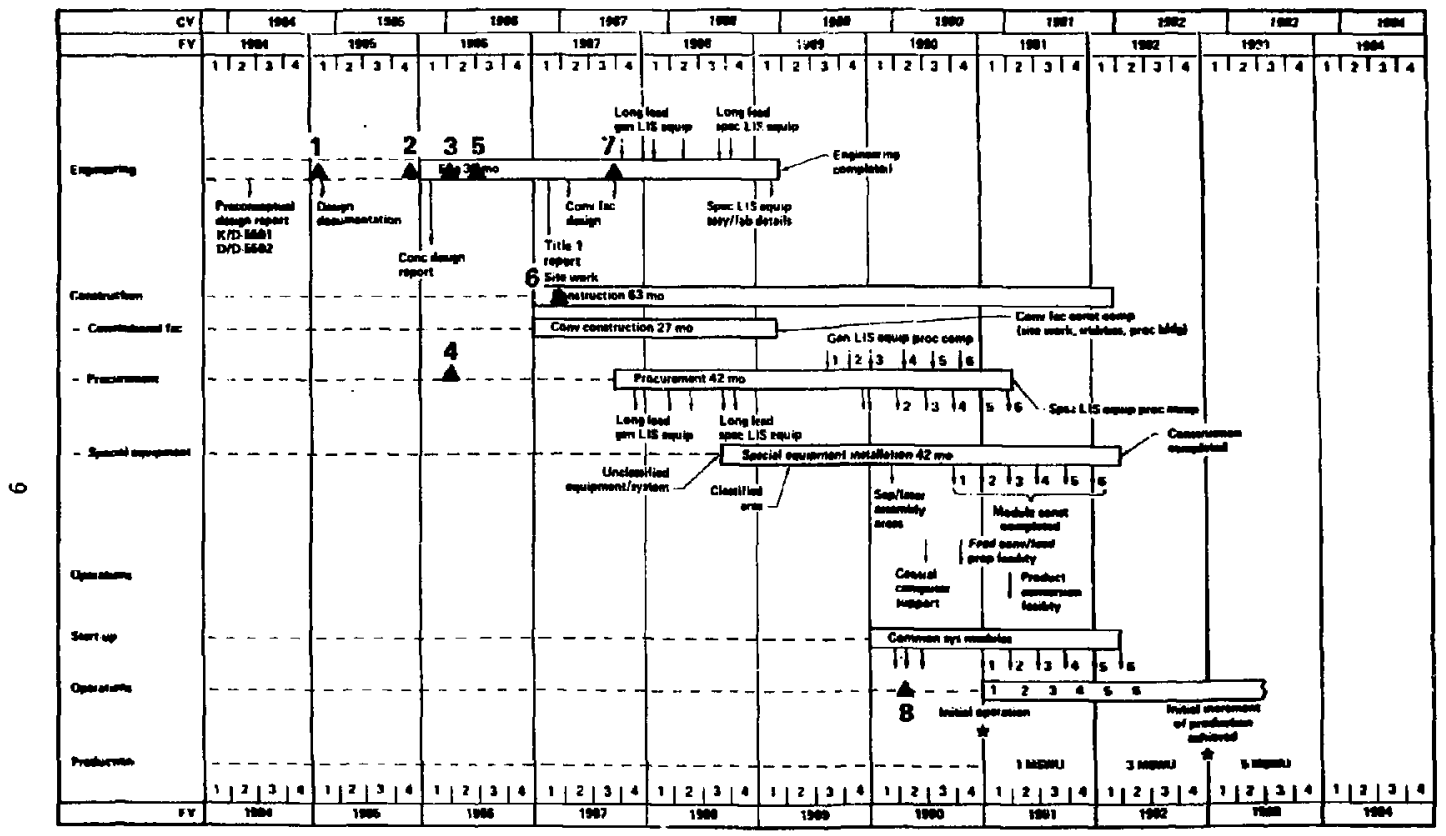

Fig. 1-1. Quality Assurance Program Key Milestones. See Table 5-4 for Milestone Definition and Number 


\section{ORGAMIZATION AND RESPONSIBILITIES}

Design and construction of the AULIS Production Plant will be accomplished under the direction of the U.S. Department of Energy (DOE), by Martin Marietta Energy Systens, Inc., and Lawrence Livermore Mationa? Laboratory (LLML) working as an integrated team. The team will be assisted by one or more architect/engineers for facility design; a construction manager; one or more fixed-price contractors for construction; a cost-plus-award-fee contractor for construction; and subcontractors to the operating contractors. Where feasible, procurement and construction will be awarded on the basis of advertised competitive bids.

The project will be organized within the existing Department of Energy structure. Project and program interfaces upon commencement of the capital project are depicted in the Project Management Plan (APP010) and are shown in Fig. 2-1. Principal participants are DOE Headquarters, the DOE Oak Ridge Operations Office (ORO), the DOE San Francisco Operations Office (SAN), the Technology Program Office (TPO), and the Operating Contractors Lawrence Livermore National Laboratory (LLNL), and Martin Marietta Energy Systems, Iric. (MWES).

The AVLIS Technical Program Office at LLNL receives direction from DOE Headquarters and is responsible for the technical management of the overall program. The Technical Program office will move to Martin Marietta after rompletion of Title II design. The Contractor Project Organization led by Martin Marietta has the prime responsiblity for executing the AUL IS Production Plant Project. The supporting technical efforts will be led by LLNL until the first plant increment is activated; thereafter, Martin Marietía will lead these activities.

Each contractor organization shall define the organizational structure within which the Quality Assurance Program is to be planned and impiemented. The organizational description shall clearly delineate the responsibilities and authority of the various personnel and organizations involved. The person responsible for the formulation and direction of the Quality Assurance Program shall have direct access to management 3 : a level where appropriate action can be initiated when required and shall report regularly on the effectiveness of the program. Persons and organizations performing Quality Assurance functions shall have sufficient authority and organizational freedom to verify conformance to quality requirements, detect early breakdowns in quality 
systems, identify and report quality problems, and initjate, recomend or provide solutions, as appropriate, through designated channels. The AVLIS Project Organization is defined in Fig. $2-2$. The organizational structure and interface between principal participants is described in detai? in the AVLIS Production Plant Project Management Plan (APPDIO).

The formulation, adminstration and surveillance of the Quality Assurance Plan is the responsibility of Martin Marietta and LLNL Managers. The various project engineers who are assigned responsfotlity for the conventional and special facilities are responsible for implementing the requirements of this plan consistent with their assigned technical responsibility.

Upon comnencement of the project, the AVLIS Production Plant Contractor Project Drganization (CPO) shall develop and implement a quality assurance program in accordance with the requirements of this document. This quality assurance program is subject to approval by the 0ak Ridge Operations - Field Project office (ORO/FPO). Contractor and subcontractor Quality Assurance Programs shall be approved by the Contractor Project Organization.

The Quality Assurance Program recognizes that the line organization is responsible for achieving and assuring the desired quaiity, reliability, and safety of its activities. This plan provides for formal controls that will be integrated within the normal management practices of the project line and engineerjng organizations to provide a nigh degree of confidence that the goals of the project will be achieved as planned.

Procedures for performance and control of work will be prepared by the line organization responsible for the work prior to start of work. Procedures shall be approved by appropriate management and reviewed by Qual ity Assurance personnel for conformance to the Quality Assurance Program requirements.

The project engineering group will be responsible for maintaining the overall status of the project and for proper dissemination of project information such as plans, schedules, budgets, estimates, and project technical and management control documents. This group will prepare the project reports.

The design and systems engineering include Titles I, II, and III as well as analyses, reiliability engineering, criteria verification, test plans, operability and maintainability plans, parts lists, and standardization. 


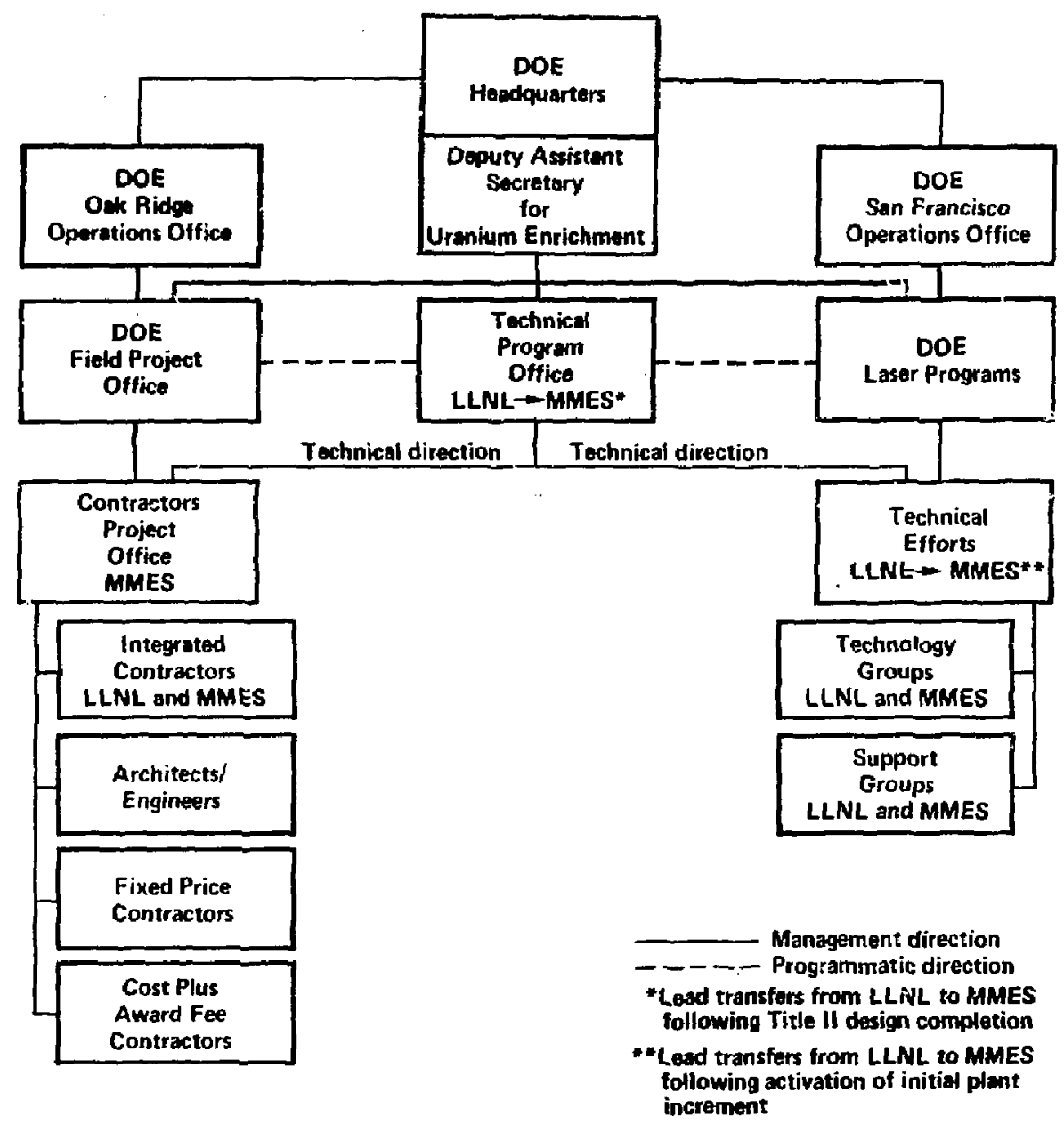

Fig. 2-1. Organization of Project for AVLIS Production Plant. 


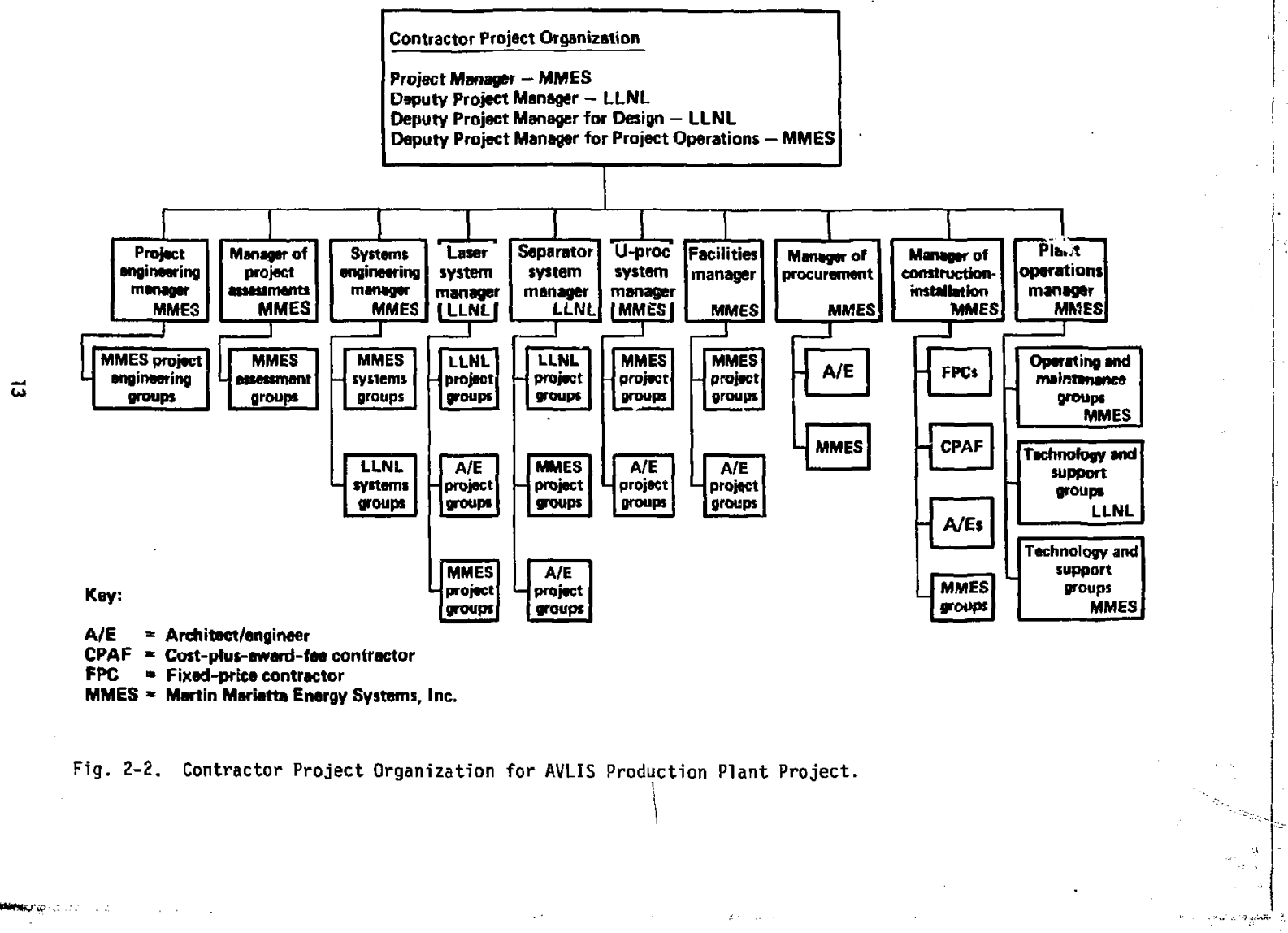


Procurement and construction include the acquisition, fabrication, installation, and some activation of the facilities and equipment. Procurement activities are described in the Industrial Access Program (PP020).

Training and safety influence the plant design, but pertain primarily to the skills and procedures needed to successfully operate the facility. Quality assurance supports all of the above activities to enhance the success of the deployment. 


\section{QUALITY ASSURANCE ACTION ELEMENTS}

The purpose of this section is to define commonly referenced quality assurance action elements. Although these elements are frequently used in project management activities, it is necessary for all project participants to have a common understanding of the quality assurance action elements. The selection and application of these elements in quality assurance plans are determined by the concerns identified through the quality assurance assessment process.

\subsection{DESIGN CONTRDL}

Design activities, including design changes, interfaces, reviews and checking shall be defined, controlled, and verified in accordance with written procedures and instructions to assure that applicable design bases and quality standards are correctly translated into design decunents. Deviations from the original design requirements, including the supporting engineering justification, shall be controlled.

Design control measures such as design reviews, alternate calculations, or performance of suitable tests shall be applied to check the adequacy of design. Adequacy of design shall be verified by persons other than those who designed the item.

\subsection{PROCUREMENT CONTROL}

\subsubsection{Procurement Document Control}

Review, approval, and revision of procurement documents shall be performed in accordance with written procedures to assure that items and/or services purchased directly or through sub-suppliers conform to the applicable technical specification and other requirements necessary to assure adequate quality. Documents providing evidence that items or services conform to the requirements of procurement documents shall be retained and must be sufficient to validate that these requirements are met. 
As appropriate, procurenent docunents shall require sub-suppliers to use a quality assurance program consistent with specificed quality requirements.

\subsubsection{Subcontractor Control}

Quality of construction is verified through surveillance inspection of construction activities performed at random or selected stages of construction.

Subcontractors on-site implementation of their quality control programs shall be monitored by quality control engineers for:
- Training and certification of personnel.
- Installation, inspection, exanination and test control.
- Control of nonconforming items.
- Documentation and records control.
o Welding and nondestructive examination control.

\subsection{INSTRUCTIONS, PROCEDURES, AND DRANINGS}

Approved instructions, procedures, and drawings shall be used to prescribe and accomplish activities affecting quality. These documents must be appropriate to the circumstances and include appropriate acceptance criteria for detemining that important activities are satisfactorily accomplished.

\subsection{DOCLMENT CONTROL}

Documents such as instructions, procedures, calculations, specifications, and drawings (including changes thereto) prescribing activities affecting quality shali be controlled. Documents shall be reviewed for adequacy and approved for release by authorized personnel. Changes to documents shall also be reviewed for adequacy and approved for release by the same organizations that performed the original review and approval.

Means shall be provided for prompt and accurate distribution of both original documents and subsequent revjsions to minimize the risk of inadvertent use of superseded or obsolete material. 
A controlled project file shall be established and maintained. Control logs which identify the document, its subject, and its status shall be maintained for documents such as bid packages, vendor drawings and correspondence.

\subsection{CONTROL OF PURCHASED MATERIALS, EQUIPWENT AND SERVICES}

Assurance that materials, equipment, and services purchased directly or through sub-suppliers conform to procurement documents shall be achieved in accordance with procedures that include, as appropriate, provisions for (1) source evaluation and selection, (2) objective evidence of quality, (3) inspection at the sub-supplier source, and (4) examination of products upon delivery. Documentary evidence that materials and equipment conform to procurement requirements shall be availeble prior to installation or use of such materials and equipment. This documentation shall be retained and must be sufficient to identify the specific requirenents such as codes, standards, or specifications met by the purchased materials and equipment. Segregation and control of rejected material shall be clearly identified.

\subsection{IDENTIFICATION AND CONTROL OF MATERIALS, PARTS, AND COMPONENTS}

Procedural controls shall be established for the identification and control of materials, parts, and components, including partially fabricated assemblies. Materials, parts, and components shall be designated for identification control through either heat number, certification, lot number, or other appropriatè means traceable to the itens. In cases where identification marking must be removed, substitute identification or traceability shall be provided. These identification and control measures are designed to prevent the use of incorrect of defective materials, parts, and components. 


\subsection{CONTROL OF SPECIAL PROCESSES}

Special processes (including welding, heat treating, and nondestructive examination) used in fabrication of products shall be controlled by using appropriate standards and qualified procedures. Procedures shall be reviewed, approved and maintained on file. Personnel involved in special processes shall be qualified. Specification and referenced code requirements for certification of welders, nondestructive examination and inspection personne 1 shall be reviewed with subconsiactors.

\subsection{INSPECTION}

Inspection criteria and instructions shall be provided by or for organizations periorming activities affecting quality. These inspections verify conformance with documented specifications, instructions, procedures, and drawings for accomplishing the activity. Inspections shall be made by qualified personnel other than those directly performing the activity. Inspection results shall be documented.

Inspection or process monitoring (or both) shall be utilized for control where needed to verify conformance with requirements. When mandatory inspection hold points are specified, work shall not proceed without the consent of the procuring organizations designated personnel. Consent to waive hold points shall be recorded prior to continuation of work beyond the hold point. Source inspection, shop inspection and like operations away from the work site shall be performed by knowledgable engineering personnel.

\subsection{TEST CONTROL}

Tests required to verify conformance of an item to specified requirements and to demonstrate that jtems will perform satisfactorily for the service intended shall be controlled by authorized written test procedures. Test procedures must assure that the prerequisites for a given test are met, that adequate test instrumentation is used, and that the test is performed under suitable environmental conditions. Tests shall be monitored by qualified 
personnel and test results shall be documented and evaluated to assure that the requirements are satisfied. Documented test results shall be retained. Test records shail, as a minimum, identify: items tested, tester or data recorded and date of test, type of observations; test results or acceptability, and reference to action taken in connection with nonconforming i tems.

The test program shall include, as appropriate:

- Prototype qualification tests.

- Proof tests prior to installation.

- Construction tests.

o Preoperational tests.

- Operational tests during facility operation.

3.10. CONTROL OF MEASURING AND TEST EQUIPMENT

Measuring and test equipment used in activities affecting quality shall be controiled and calibrated to maintain accuracy within necessary limits. The degree of control and frequency of calibration shall be commensurate with the significance of the activity or equipment, and within the accuracy tolerances and calibration frequency established by the equipment and manuf acturer.

Measuring and test equipment shall be calibrated against equipment that has a known valid relationship to nationaliy known standards. If no national standard exists, the basis for calibrations shall be documented.

Documentation of calibration data shall be preserved. Equipment shall be suitably marked to indicate status of caljbration.

\subsection{HANDLING, STORAGE, AND SHIPPING}

Handling, storage, shipping, cleaning, packaging, marking, labeling, and preservation of materials and equipment shall be defined and controlled in accordance with written procedures to prevent damage or deterioration. Special protective environments, such as inert gas atmospheres, specific moisture levels, and temperatires, shail be provided as appropriate. 


\subsection{INSPECTION, TEST, AND OPERATING STATUS}

Appropriate controls shall be applied to indicate the status of inspections and tests performed and to prevent the inadvertent use of items that have not passed the required tests and inspections. The authority for application and removal of indicators of the operating status of structures, systems, and components of the facijity, such as tagging valves and switches to prevent inadvertent operation, shall be specified.

Prior to final equipment acceptance all required quality records and other information required by contract, shall be turned over to the procuring organization.

\subsection{CONTROL OF NGNCONFORMING ITEMS}

Measures shall be established to control construction and production of materials, parts, or components which do not conform to requirements in order to prevent their inadvertent use or installation. These measures shall include, as appropriate, procedures for identification, documentation, segregation, disposition, and notification to affected organizations. Nonconforming items shall be reviewed and accepted, rejected, repaired, or reworked and reinspected in accordance with documented procedures.

Material and equipment discovered to be discrepant upon receipt shall be segregated from acceptable material by either tagging, marking, separated storage, or other similar appropriate means to prevent inadvertent use of the discrepant item, and a log maintained.

\subsection{SOFTWARE CONTROL}

The Quality Assurance Program applies to the development of software or the software product for the design, development, testing, and utilization of AVLIS programs. The program shall address the detection, reporting, analysis, and correction of software deficiencies associated with computer processing.

The responsible contractor(s) shall implement a Software Quality Assurance Program consistent with the requirenents of this document which 
include practices and procedures to assure compliance with all software requirements and specifications. The Plan shall identify organizational responsibilities and authorities for its execution and the events critical to its implementation.

The Plan shall address as a minimum:

- Design Reviews.

- Integration Testing \& System Testing.

- Validations Verification.

- Configuration Management.

- Access Control.

\subsection{QUALITY ASSURANCE RECORDS}

Sufficient records shall be maintained to document activities affecting quality as required in the technical specifications. The records include drawings, procurement documents, calculations, and operating logs; results of reviews, inspections, tests, audits, monitoring or work performance, and material analyses; and qualification of personne1, procedures and equipment. Records shall be identifiable and retrievable. Retention periods shall be specified. Records shall be protected against damage, deterioration, or Joss.

\subsection{SAFETY CONTROL}

The safety control will minimize the risks of accident by the early detection of significant potential hazards inherent in the design of the AVLIS conventional and special facilities. It will assess the impact of the hazards identified on the health and safety of employees and public, and the environment. It will apply the appropriate design, barricades, warnings, and management controls to eliminate or control the accident risks to an acceptable level.

The controls include identification of hazards, assessment of risks, designing for minimum risk, incorporation of safety devices or systems, and establishment of pasitive administration controls. 


\section{PRELIMINARY RISK ASSESSMENT}

\subsection{INTRODUCTION}

This section provides a preliminary risk assessment of the major systems and components of the AVLIS Production Plant, and the impact of failure of these systems on the successful completion and operation of the plant. The criteria and methodology used in performing the preliminary assessment are defined, and the results of the assessment are summarized. Subsequent assessments will focus on further details of the work breakdown structure during the Title I project phase.

\subsection{SCEPE}

The purpose of this risk assessment is to provide a preliminary identification of those Work Breakdown Structure elements of the AVLIS Production Plant that are considered most important to the successful operation of the plant.

The assessment was performed by using engineering judgement to determine the consequences and probabjlities for various failures. In certain areas limited engineering analyses where conducted to obtain more accurate estimates of the impacts. Detailed descriptions of the systems and components analyzed are contained in the following documents:
EB030 AVLIS Production Plant Laser System Design Report
EB040 AVLIS Production Plant Separator System Design Report
EB050 AVLIS Production Plant Uranium Processing Design Report
EB060 AVLIS Production Plant Conventional Facilities and Process Design Report

If an item is considered critical, special actions as explained in Sec. 5 will be initiated during the design, procurement, construction, or operation phases. These special actions will be identified during the early design phase. Once specific actions are identified the Quality Assurance program will monitor project activities to ensure that these actions are followed. 
Conventional facilities and systems which are not unique to the AVLIS technology or are cominercially available have been selectively screened from this preliminary assessment in order to focus attention on AVLIS Production Plant special equipment and uranium processing.

As a follow-on to this preliminary risk assessment, a more detailed risk assessment will be conducted early in the design phase. Each organization and discipline including Quality Assurance personnel participating in the Project shall contribute to the assessment process. The knowledge and experience of all disciplines will then be an advantage in the prevention of quality problems. In concert with this activity all design groups shall forward copies of approved Quality Assurance Assessments to each particjpant having interface responsibilities which need to be addressed as a result of the assessment process.

The Quality Assurance Assessments shall be initiated and completed by the 30\% Design Review milestone. Reassessments shall be ir itiated at project major milestones (60\%, $90 \%$ anci certified for construction design reviews) or when the previous assessments have been invalidated by design changes.

\subsection{METHODOLOGY}

This preliminary risk assessment was conducted with the intent of identifying the level of project risk for each major project system if that system or component did not perform satisfactorily in service. The basis used to divide the plant into elements was the Work Breakdown Structure, Fig. 4-1. 
LEVEL

AVLIS Production Plant wor

1

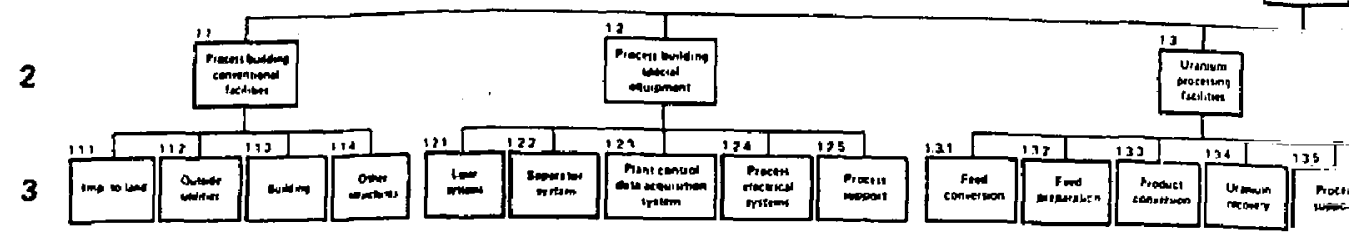

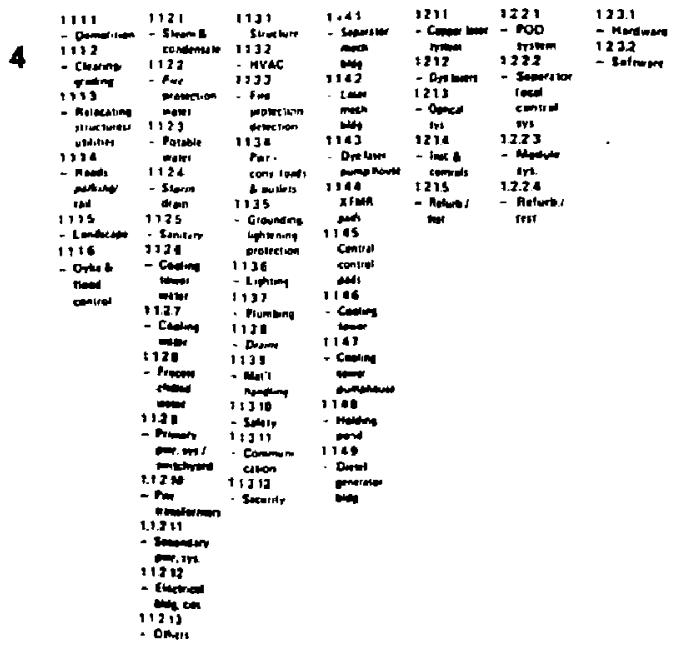

wiss alements impuctud by fully at

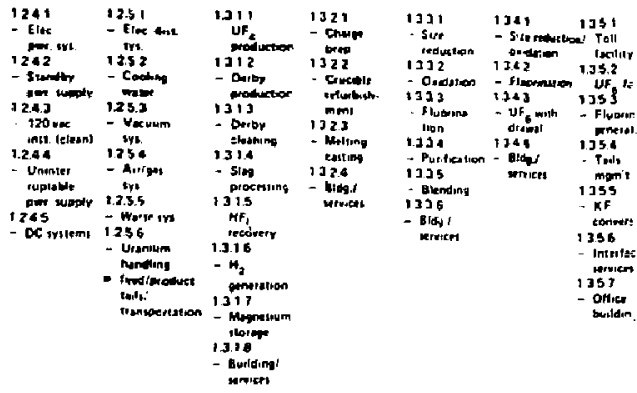

Fig. 4-7. AVLIS work Breakdown Structure. 

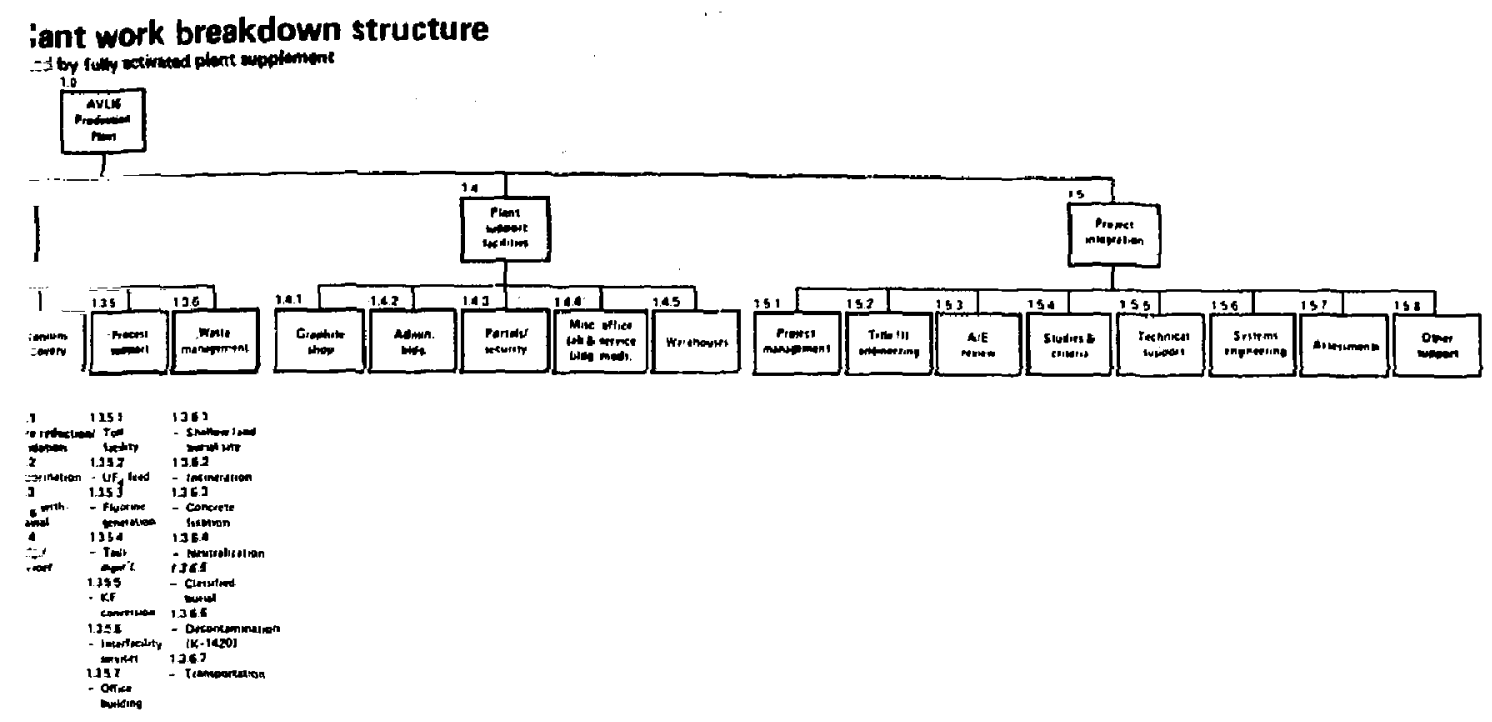
The methodology is sumarized in Fig. 4-2. In determining risk, both the consequence of failure and the probabjlity of failure are considered.

\subsubsection{Consequence Level}

Each item was evaluated to determine the consequence of a failure. Potential failures which cause the function of the component to be lost or which cause damage to additional components were identified. No attempt was made to identify all possible causes of failure. Rather, the effort was to identify the more serious failure modes to determine if further consideration was necessary.

Once a failure effect was identified the consequences of the failure were determined. The importarce of the failure was assessed by comparison to criteria identifying significant failures. The criteria for consequence of failure used in this assessment are presented in Table 4-1.

The consequence of a failure has been catagorized as either significant, moderate, or insignificant $(S, M, I)$. Failures which result in consequences which exceed any one of the criteria presented in Table 1 would be classified as significant. An insignificant failure has little or mo impact on day-to-day operations. A moderate failure is one that falls somewhere between the two failures described above. A maderate failure would require a noticable reallocation of resources over and above what is considered day-to-day operations.

\subsubsection{Probability Factor}

After determining the consequence of failure, it is necessary to evaluate the probability of failure. Equipment repair or replacement required as a result of normal operation is anticipated. As a result refurbishment facilities are being provided and a preventive maintenance program will be implemented. The objective of this assessment is to consider failure modes which are beyond those anticipated during normal operation and which due to their random occurrence may require additional design provisions. The probability of failure has been catagorized as high, moderate, low, or very 


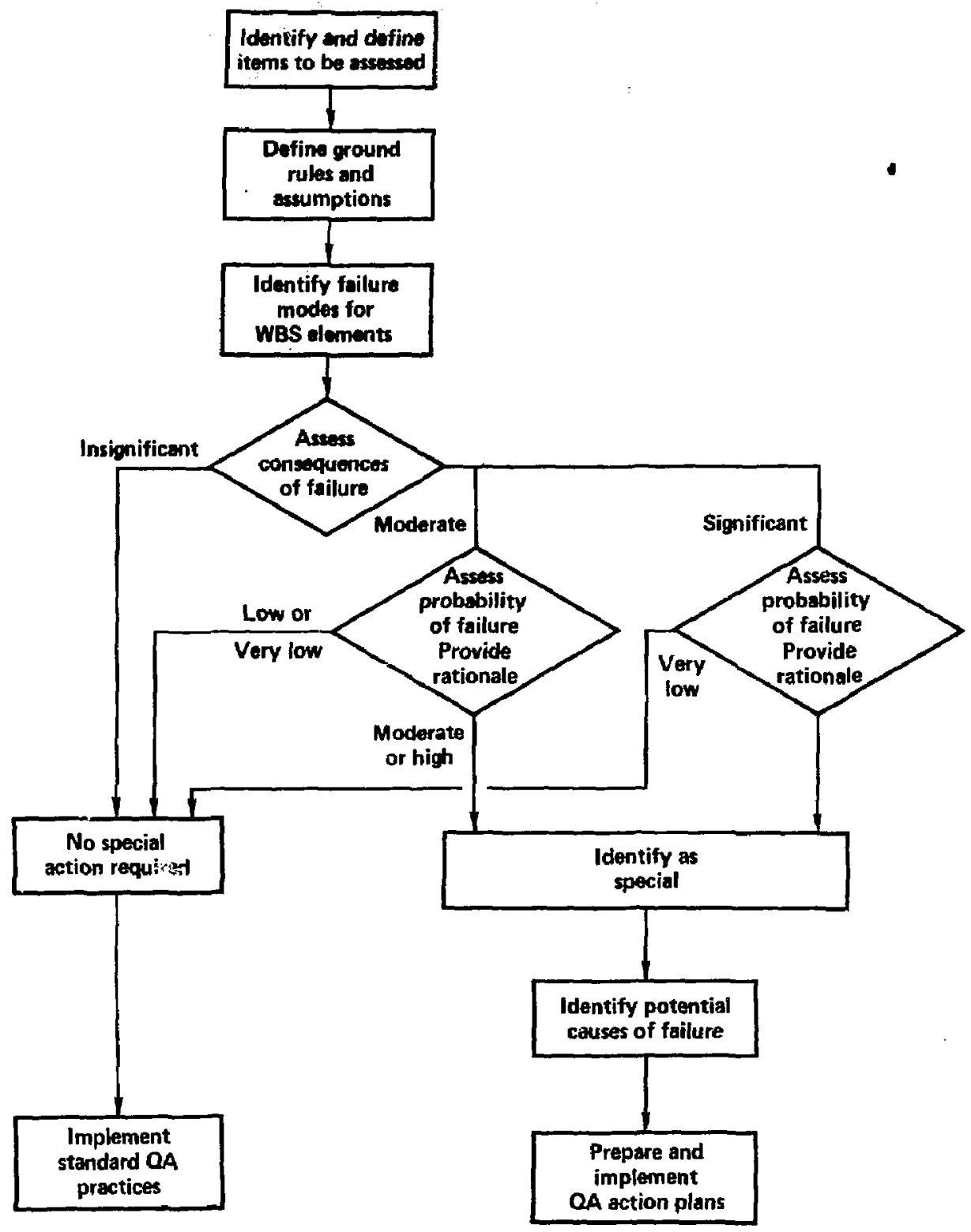

Fig. 4-2. Qualitative Assessment Procedure. 
Table 4-1, Criteria for Defining Consequence of Failure.

1. Do not consider failures caused by:

Labor union strikes

Sabotage or vandalism

Acts of war

2. Failure Consequences Classification:

For the purpose of classifying the consequences of failure, the definition of "significant fallure" is, "the effect of primary failure which can result in any one of the following consequences":

A. Radiation Safety addresses radiation exposures to personnel and members of the general pubtic as a result of the accidental release of radioactive material. For any event, the dose-equivalent received by the maximally exposed off-site individual shall not exceed either:

1. A weighted whole body 50 -year dose commitment of $500 \mathrm{millirem,}$ using the methodology. out]ined in ICRP Publication 26 for weighting and summing doses to individual organs; or

2. A dose-equivalent of 5000 millirem to the hands and forearms, feet and ankles, skin, or lens of the eye.

B. Unanticipated Costs are those costs which result from accidents or other unexpected events, which are considered unacceptable. Costs associated with equipment replacement (both labor and materials), repair of damage, clean-up of radioactive contamination, and loss of production are included.

C. Process Hazards that may result in death or serious injury to operating personnel as a result of the special or unusual hazards associated with laser isotope separation. Normal industrial hazards are not covered by this criterion.

D. Criticality addresses those engineered safety features incorporated into the plant primarily to preclude the occurrence of an accidental nuclear excursion. Devices which only mitigate the severity of a criticality (such as shielding or evacuation alarms) do not fall under this criterion.

3. System redundancy should not be considered the sole mitigating factor in the reduction of failure probability. Redundancy, however, is an appropriate design Quality Assurance action when utilized in an attempt to reduce the risk associated with the system. 
low $(H, M, L, V L)$. In this qualitative assessment a high probability of failure is one in which an unanticlpated failure is likely to occur at a rate greater than approximately once every five years. A moderate probability of failure implies that the failure will occur on an occassional basis. The frequency for moderate probability events ranges from once every 5 years to once during the plant lifetime (about 30 years).

When the failure rate for a component is between once during the plant lifet ine and once every 1,000 years it is classiffed as low. Certain failure modes are considered to be very rare or improbable. The very Iow probability for certain fallures could result from the use of components wich have a very high inherent reliabllity, or a need for several high reliabllity components to fail before an adverse consequence occurs. Failure rates for components in this range would be below once every 1,000 years.

\subsubsection{Risk Evaluation}

Equipment fajlure which result in significant consequences do not necessarily require the application of special Quality Assurance requirements. Similarly, components with high fajlure rates may not require special actions. The evaluation of which events require a special action must consider the combination of consequence and probability. This combination defines the risk of a given failure. Those items that have a high degree of risk require special actions if the risk is to be reduced. Figure 4-3 provides a matrix for determination of whether the risk is considered sufficient to warrant special actions for the purposes of this preliminary assessment. The assessment process provides a logical approach for determining where special attention should be applied to assure operational success. Where there is relatively little or no risk, special actions are not required. However, as the degree of risk increases it becomes more prudent to apply greater measures to assure success. When the consequence of failure is high and the probability of failure is high, the risk is high. At the other extreme, where the consequence of failure is insignificant and the probability of failure is low, the risk is low. When a particular item has a low risk evaluation, there is seldom any benefit to applying additional valuable resources to further reduce the risk. 


\begin{tabular}{|c|c|c|c|c|}
\hline \multirow{2}{*}{$\begin{array}{l}\text { Consequence } \\
\text { of failure }\end{array}$} & \multicolumn{4}{|c|}{ Probability of failure } \\
\hline & $\begin{array}{l}\text { High } \\
\mathrm{F}>.2 / \mathrm{yr}\end{array}$ & $\begin{array}{c}\text { Moderate } \\
.2 / y r>F>.03 / y r\end{array}$ & $\stackrel{\text { Low }}{.03 / y r}>\mathrm{F}>10^{-3} / \mathrm{yr}$ & $\begin{array}{l}\text { Very low } \\
F<10^{-3} / y r\end{array}$ \\
\hline Significant & & & & \\
\hline Moderate & & & & \\
\hline Insignificant & & & & \\
\hline
\end{tabular}

$X$ - special action required

Fig. 4-3. Matrix for determination of special action classification. 


\subsection{RESULTS}

The results of the pretiminary risk assessment are summarized in Tables 4-2 through 4-13. The assessments are grouped by Work Breakdown Structure elements as indicated below:

WBS No. System Table

1.2.1. Laser Systems

1.2.1.1. Copper Laser System

1.2.1.2. Dye Lasers 4-3

1.2.1.3. Optical Sÿstens

4-4

1.2.1.5. Refurbishment/Test

$4-5$

\subsubsection{Separator System}

1.2.2.1. Pod System

4.6

1.2.2.3. Module System

1.2.2.4. Refurbishment/rest

1.3. Uranium Processing
1.3.i. Feed Conversion
4-9
1.3.2. Feed Preparation
4-10
1.3.3. Product Conversion
4-11
1.3.4. Uranium Recovery
4-12
1.3.5. Process Support
4-13

The items requiring special action are identified in the column on the worksheet by a "yes" or as appropriate with a "no". A "no" in the column referring to special actions means that at the time of this preliminary assessment there was adequate confidence that the Work Breakdown Structure items, system nr subsystem, as presently planned, would perform as intended without additional quality assurance actions beyond those currently utilized or a failure would have insignificant adverse impact on plant performance or 
avallability. A "yes" in the special action column means that at the time of the assessment there was suficicient risk to warrant formal application of special Quality Assurance actions. The implementation of these special actions is discussed in Sec. 5 .

In reviewing the results of this preliminary assessment, it is necessary

c to understand that, as part of the AVLIS Production Plant Project Management Plan, detailed technical assessments will be conducted during the engineering desiyul phase and completed prior to the issue of the Title I Engineering Report. It is in these detailed assessments that specfic special actions will be identifled. 
Table 4-2. Preliminary Risk Assessment for MBS 1.2.1.1 Copper Laser System.

\begin{tabular}{|c|c|c|c|c|c|c|}
\hline $\begin{array}{l}\text { HeS Ho. } \\
\text { item name }\end{array}$ & $\begin{array}{l}\text { Potential } \\
\text { failure }\end{array}$ & $\begin{array}{l}\text { Failure } \\
\text { effect }\end{array}$ & $\begin{array}{l}\text { Consequence } \\
\text { of failure } \\
(\mathrm{S}, \mathrm{M}, \mathrm{I})\end{array}$ & $\begin{array}{l}\text { Probability } \\
\text { of failure } \\
(H, M, L)\end{array}$ & $\begin{array}{l}\text { Soecial } \\
\text { action } \\
\text { required } \\
\text { (yes/no) }\end{array}$ & Coments \\
\hline $\begin{array}{l}\text { 1.2.7.1.1 } \\
\text { Copper iaser } \\
\text { oscitiator }\end{array}$ & $\begin{array}{l}\text { Failure of any } \\
\text { of the follow- } \\
\text { ing: Head, } \\
\text { optics, enc1., } \\
\text { vec. sys, } \\
\text { electrizai }\end{array}$ & $\begin{array}{l}\text { Loss of one } \\
\text { copper laser } \\
\text { power ampli- } \\
\text { fier chain }\end{array}$ & I & $H^{(a)}$ & No & $\begin{array}{l}\text { There are approximately } 100 \text { copper } \\
\text { laser oscjiliatars per laser } \\
\text { module. (b) Units are independent } \\
\text { so that loss of one unit does } \\
\text { not affect operation of other } \\
\text { units. Loss of a single chain has } \\
\text { a minor impact on plant performance. }\end{array}$ \\
\hline $\begin{array}{l}1.2,1,1.2 \\
\text { Copper iaser } \\
\text { amplifier }\end{array}$ & $\begin{array}{l}\text { Failure of any } \\
\text { of the follow- } \\
\text { ing: Head, } \\
\text { optics, enc1.. } \\
\text { vac. Sys., } \\
\text { electrical }\end{array}$ & $\begin{array}{l}\text { Max. impact } \\
\text { is loss of } \\
\text { one copper } \\
\text { laser power } \\
\text { anplif ter } \\
\text { chain }\end{array}$ & I & $H^{(a)}$ & No & $\begin{array}{l}\text { There are approximate)y } 200 \text { copper } \\
\text { laser amplif ters per laser module. } \\
\text { Loss of a single unit causes a } 30 \% \\
\text { reduction in power output for one } \\
\text { chain. Haximum inpact is loss of } \\
\text { one chain. Loss of a single chain } \\
\text { has a minor impoct on plant } \\
\text { perfomance. }\end{array}$ \\
\hline $\begin{array}{l}1.2 .1 .1 .3 \\
\text { Herriot cel1s }\end{array}$ & $\begin{array}{l}\text { Mechanical } \\
\text { failure of } \\
\text { optics } \\
\text { dligmment }\end{array}$ & $\begin{array}{l}\text { Loss of one } \\
\text { copper laser } \\
\text { power ampli- } \\
\text { fier chain }\end{array}$ & 1 & $\mathbf{L}$ & no & $\begin{array}{l}\text { There are approximately } 100 \text { Herriot } \\
\text { cells per laser module. Units } \\
\text { are independent so that loss of } \\
\text { one unit does not of fect operation } \\
\text { of other units. Loss of a single } \\
\text { unit has a minor impact on plant } \\
\text { performance. }\end{array}$ \\
\hline
\end{tabular}

(a) Scheduled maintenance for units is 5000 hours.

(b) Module serves either dye broster amplifier or dye power amplifier. 
Table 4-3. Preliminary Risk Assessment for WBS 1.2.1.2 Oye Lasers.

\begin{tabular}{|c|c|c|c|c|c|c|}
\hline $\begin{array}{l}\text { HBS No. } \\
\text { item nane }\end{array}$ & $\begin{array}{l}\text { Potential } \\
\text { failure }\end{array}$ & $\begin{array}{l}\text { Failure } \\
\text { effect }\end{array}$ & $\begin{array}{l}\text { Consequence } \\
\text { of failure } \\
(5, M, 1)\end{array}$ & $\begin{array}{l}\text { Probability } \\
\text { of fallure } \\
(H, M, L)\end{array}$ & $\begin{array}{l}\text { Special } \\
\text { action } \\
\text { required } \\
\text { (yes/no) }\end{array}$ & Comment s \\
\hline \multirow[t]{2}{*}{$\begin{array}{l}1.2 .1 .2 .1 \\
\text { Dye wave } 10 \mathrm{~m} \\
\text { generator }\end{array}$} & $\begin{array}{l}\text { Failure of } \\
\text { electronics/ } \\
\text { temperature } \\
\text { controller } \\
\text { of one dye } \\
\text { master } \\
\text { oscillator }\end{array}$ & No impact & 1 & $M$ & No & $\begin{array}{l}\text { Spare dye maste. oscillators are } \\
\text { provided for ejen color to } \\
\text { provide redundancy. Units can } \\
\text { be replaced in about one hour. }\end{array}$ \\
\hline & $\begin{array}{l}\text { failure of } \\
\text { both oye } \\
\text { master } \\
\text { oscillators } \\
\text { for a itngle } \\
\text { color at the } \\
\text { some tine }\end{array}$ & $\begin{array}{l}\text { Loss of plant } \\
\text { separative } \\
\text { capacity until } \\
\text { defective units } \\
\text { are replaced }\end{array}$ & ts & VL & No & $\begin{array}{l}\text { The lower fallure rate of these } \\
\text { components conbined with the } \\
\text { short replacenent time rerult in a } \\
\text { small risk. }\end{array}$ \\
\hline $\begin{array}{l}\text { Copper Iaser } \\
\text { oscillator }\end{array}$ & $\begin{array}{l}\text { Foilure of any } \\
\text { of the follow- } \\
\text { ing: head, } \\
\text { optics, encl.. } \\
\text { electrical. } \\
\text { vac. sys. }\end{array}$ & $\begin{array}{l}\text { Loss of one } \\
\text { copper laser } \\
\text { oscillator }\end{array}$ & I & $H(\mathbf{a})$ & Ho & $\begin{array}{l}\text { There are many copper laser oscil- } \\
\text { lators for the dye master oseil. } \\
\text { lators. Fewer are required for } \\
\text { operation. Loss of one will nave } \\
\text { no effect on plant availability. }\end{array}$ \\
\hline $\begin{array}{l}1.2,1.2 .3 \\
\text { Dye anplif iers }\end{array}$ & $\begin{array}{l}\text { Fallure of } \\
\text { window }\end{array}$ & $\begin{array}{l}\text { Loss of one } \\
\text { dye anpli- } \\
\text { fier chain }\end{array}$ & $M$ & $\mathbf{L}$ & no & $\begin{array}{l}\text { Interlocks provided to stop loss } \\
\text { of alcohol through broken windaw } \\
\text { (sensors detect presssure drop) } \\
\text { and once through ventilation } \\
\text { provided to remove vapors. }\end{array}$ \\
\hline $\begin{array}{l}1.2 .1 .2 .3 \\
\text { Dye amplifiers }\end{array}$ & $\begin{array}{l}\text { Leak of dye } \\
\text { flow system } \\
\text { containment. }\end{array}$ & $\begin{array}{l}\text { Loss of one } \\
\text { anplifier } \\
\text { chain }\end{array}$ & H & $\mathbf{L}$ & Ho & $\begin{array}{l}\text { Automatic valves close as } \\
\text { pressure flow rate drops. } \\
\text { Ethanol sensors detect vapors. } \\
\text { 0nce through ventilation provided } \\
\text { to remove yapors. fire } \\
\text { suppression system provided. }\end{array}$ \\
\hline Dye pumps & $\begin{array}{l}\text { Loss of pump } \\
\text { due to mechan- } \\
\text { ical or elec- } \\
\text { trical failure }\end{array}$ & $\begin{array}{l}\text { Loss of one } \\
\text { pump has no } \\
\text { impact. }\end{array}$ & I & $L$ & No & $\begin{array}{l}\text { Each loop has standby pump. } \\
\text { Mean-time-between-fatlures (MTBF) } \\
\text { is approx imately } 63,000 \text { hrs. for } \\
\text { each pump. }\end{array}$ \\
\hline
\end{tabular}

(a) Scheduled maintenance for units is 5000 nours. 
Table 4-4. Preliminary Risk Assessment for LBS 1.2.1.3 Optical System.

\begin{tabular}{|c|c|c|c|c|c|c|}
\hline $\begin{array}{l}\text { NeS No. } \\
\text { item name }\end{array}$ & $\begin{array}{l}\text { Potential } \\
\text { fallure }\end{array}$ & $\begin{array}{l}\text { Failure } \\
\text { effect }\end{array}$ & $\begin{array}{l}\text { Conseguence } \\
\text { of } \mathrm{fallure} \\
(\mathrm{S}, \mathrm{m}, \mathrm{I})\end{array}$ & $\begin{array}{l}\text { Probability } \\
\text { of failure } \\
(H, M, L)\end{array}$ & $\begin{array}{l}\text { Spectal } \\
\text { action } \\
\text { required } \\
\text { (yes/mo) }\end{array}$ & Coments \\
\hline$\frac{1.2 .1 .3}{0 \text { pticit systen }}$ & $\begin{array}{l}\text { Mechanical } \\
\text { fatlure }\end{array}$ & $\begin{array}{l}\text { Partial loss } \\
\text { of phototon- } \\
\text { ization }\end{array}$ & $M$ & L & no & $\begin{array}{l}\text { Components have a low fallure } \\
\text { potential during norial } \\
\text { operation }\end{array}$ \\
\hline
\end{tabular}

Table 4-5. Preliminary Risk Assessment for HBS 1.2.1.5 Refurbishment and Test.

\begin{tabular}{|c|c|c|c|c|c|c|}
\hline $\begin{array}{l}\text { WBS Ho. } \\
\text { item name }\end{array}$ & $\begin{array}{l}\text { Potential } \\
\text { failure }\end{array}$ & $\begin{array}{l}\text { Failure } \\
\text { effect }\end{array}$ & $\begin{array}{l}\text { Consequence } \\
\text { of } f \text { aflure } \\
(S, M, I)\end{array}$ & $\begin{array}{l}\text { Probability } \\
\text { of failure } \\
(\mathrm{H}, \mathrm{M}, \mathrm{L})\end{array}$ & $\begin{array}{l}\text { Special } \\
\text { action } \\
\text { required } \\
\text { (yes/no) }\end{array}$ & Comments \\
\hline $\begin{array}{l}\frac{1.2 .1 .5}{\text { Refurbishment and }} \\
\text { Eest }\end{array}$ & $\begin{array}{l}\text { Equipment } \\
\text { failures }\end{array}$ & $\begin{array}{l}\text { Increased } \\
\text { refurbishment } \\
\text { times }\end{array}$ & t & M & no & $\begin{array}{l}\text { Faflure of equipment in the } \\
\text { refurbishment and test areas } \\
\text { does not cause loss of plant } \\
\text { separat ive capacity. However } \\
\text { such faliures could imiact } \\
\text { refurbishment times. }\end{array}$ \\
\hline
\end{tabular}


Table 4-6. Preliminary Risk Assessment for WBS 1.2.2.1 Pod System.

\begin{tabular}{|c|c|c|c|c|c|c|}
\hline $\begin{array}{l}\text { HBS No. } \\
\text { item none }\end{array}$ & $\begin{array}{l}\text { Potential } \\
\text { failure }\end{array}$ & $\begin{array}{l}\text { Failure } \\
\text { effect }\end{array}$ & $\begin{array}{l}\text { Consequence } \\
\text { of failure } \\
(\mathrm{S}, \mathrm{M}, \mathrm{I})\end{array}$ & $\begin{array}{l}\text { Probability } \\
\text { of failure } \\
(H, M, L)\end{array}$ & $\begin{array}{l}\text { Specfal } \\
\text { action } \\
\text { required } \\
\text { (yes } / \text { no) }\end{array}$ & Coments \\
\hline $\begin{array}{l}1.2 .2 .1 .1 .1 \\
\text { E-beam system }\end{array}$ & $\begin{array}{l}\text { Single gun } \\
\text { failure }\end{array}$ & $\begin{array}{l}\text { Temporary } \\
\text { loss of heat } \\
\text { to meit }\end{array}$ & I & $H^{\mathbf{a}}$ & No & Redundant E-quns are provfded \\
\hline & $\begin{array}{l}\text { Gun power } \\
\text { system or } \\
\text { controls } \\
\text { fatlure }\end{array}$ & $\begin{array}{l}\text { Loss of heat } \\
\text { to melt, } \\
\text { premature } \\
\text { separator } \\
\text { shutdown }\end{array}$ & $\mathbf{I}$ & $m$ & to & $\begin{array}{l}\text { A faiture of this type would } \\
\text { result in a reduced run time for } \\
\text { a module, below the average } \\
400 \text { hours }\end{array}$ \\
\hline $\begin{array}{l}1.2 .2 .1 .1 .2 \\
\text { Cructbie melt bean } \\
\text { dump system }\end{array}$ & $\begin{array}{l}\text { Crucible } \\
\text { fatiure }\end{array}$ & $\begin{array}{l}\text { Loss of nelt } \\
\text { conta innent }\end{array}$ & $\mathbf{S}$ & $L$ & Yes & $\begin{array}{l}\text { Extended module domitime due to } \\
\text { cleamup and tnspection. }\end{array}$ \\
\hline & $\begin{array}{l}\text { Cooling water } \\
\text { suppiy headers } \\
\text { faflure }\end{array}$ & $\begin{array}{l}\text { Cooling water } \\
\text { introduced } \\
\text { into operating } \\
\text { module, loss of } \\
\text { vacuum, loss of } \\
\text { production }\end{array}$ & $\begin{array}{l}\text { of } \\
\text { of }\end{array}$ & 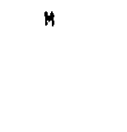 & No & $\begin{array}{l}\text { Extended module downtime due to } \\
\text { cleanup and inspection. }\end{array}$ \\
\hline $\begin{array}{l}1.2 .2 .1 .1 .3 \\
\text { Feed/reflux dist. } \\
\text { systems }\end{array}$ & $\begin{array}{l}\text { Feed system } \\
\text { faflure }\end{array}$ & $\begin{array}{l}\text { Premature } \\
\text { module } \\
\text { shutdown }\end{array}$ & $\mathbf{I}$ & $M$ & No & Replace defect ive feeder. \\
\hline & $\begin{array}{l}\text { Reflux system } \\
\text { fatlure }\end{array}$ & $\begin{array}{l}\text { Inability to } \\
\text { return mater- } \\
\text { ial to melt, } \\
\text { materiaj build } \\
\text { up on troughs, } \\
\text { material splast } \\
\text { into crucible }\end{array}$ & $\begin{array}{l}I \\
\text { sing } \\
\text { sing }\end{array}$ & $M$ & No & $\begin{array}{l}\text { This may cause premature module } \\
\text { shutdown. }\end{array}$ \\
\hline $\begin{array}{l}\text { 1.2.2.1.2.1 } \\
\text { Frate assy. }\end{array}$ & Frame failure & $\begin{array}{l}\text { Loss of } \\
\text { umbilical } \\
\text { seal, loss of } \\
\text { alignient, } \\
\text { jamming of pod } \\
\text { withdrawal } \\
\text { system }\end{array}$ & d & $\mathbf{L}$ & Ho & $\begin{array}{l}\text { Loss of the umbilical sesls during } \\
\text { operation would cause premature } \\
\text { module shutdown. }\end{array}$ \\
\hline
\end{tabular}


Table 4-6. (Continued)

\begin{tabular}{|c|c|c|c|c|c|c|}
\hline $\begin{array}{l}\text { WBS Ho. } \\
\text { item name }\end{array}$ & $\begin{array}{l}\text { Potential } \\
\text { foilure }\end{array}$ & $\begin{array}{l}\text { Failure } \\
\text { effect }\end{array}$ & $\begin{array}{l}\text { Consequence } \\
\text { of failure } \\
(5, \mathrm{w}, 1)\end{array}$ & $\begin{array}{l}\text { Probability } \\
\text { of failure } \\
(\mathrm{H}, \mathrm{M}, \mathrm{L})\end{array}$ & $\begin{array}{l}\text { Spectal } \\
\text { action } \\
\text { required } \\
\text { (yes/no) }\end{array}$ & Coments \\
\hline $\begin{array}{l}\text { l.2.2.1.2.2 } \\
\text { lhobjical seal } \\
\text { bellows }\end{array}$ & Seal fallure & $\begin{array}{l}\text { Introduction } \\
\text { of atmosphere } \\
\text { into module }\end{array}$ & I & $\mathbf{L}$ & $\mathbf{m o}_{0}$ & Covered above $(1.2 .2 .1 .2 .1\}$ \\
\hline \multirow[t]{3}{*}{$\begin{array}{l}1.2 .2 .1 .2 .3 \\
\text { Jijiity dist. } \\
\text { manifolds }\end{array}$} & $\begin{array}{l}\text { Faflure in } \\
\text { electi-ical } \\
\text { connector } \\
\text { for E-bean gun }\end{array}$ & $\begin{array}{l}\text { Loss of power } \\
\text { to E-beam gun }\end{array}$ & I & L & Ho & Switch to spare gun. \\
\hline & $\begin{array}{l}\text { Faflure in } \\
\text { electrical } \\
\text { connector for } \\
\text { heater }\end{array}$ & $\begin{array}{l}\text { Loss of power } \\
\text { to heater }\end{array}$ & I & $\mathbf{L}$ & Ho & $\begin{array}{l}\text { Loss of one heater can generally } \\
\text { be tolerated with no effect on } \\
\text { performance. }\end{array}$ \\
\hline & $\begin{array}{l}\text { Failure of } \\
\text { cooling water } \\
\text { dist. lines }\end{array}$ & $\begin{array}{l}\text { Introduction } \\
\text { of water into } \\
\text { module }\end{array}$ & $M$ & $\mathbf{L}$ & Wo & $\begin{array}{l}\text { Low pressure system, } \\
\text { Introduction of cooling water into } \\
\text { operat ing module has been pre- } \\
\text { viously discussed }(1.2 .2 .1 .2 .1)\end{array}$ \\
\hline \multirow[t]{2}{*}{$\begin{array}{l}1.2 .2 .1 .3 .1 \\
\text { Enciosure assy. }\end{array}$} & $\begin{array}{l}\text { Failure of } \\
\text { enc losure } \\
\text { component }\end{array}$ & $\begin{array}{l}\text { Ralease of U } \\
\text { vapor to module } \\
\text { interior }\end{array}$ & e & $\mathbf{L}$ & No & $\begin{array}{l}\text { Module turnaround time mould be } \\
\text { increased due to unscheduled } \\
\text { cleanup. }\end{array}$ \\
\hline & $\begin{array}{l}\text { Comportent } \\
\text { falls into } \\
\text { melt }\end{array}$ & $\begin{array}{l}\text { Melt Spl ashes } \\
\text { onto E-guns } \\
\text { and/or module } \\
\text { interior }\end{array}$ & M & VL. & No & $\begin{array}{l}\text { Module runt ine would be decreased. } \\
\text { Module turnaround time could in- } \\
\text { crease due to extended cleanup } \\
\text { time. }\end{array}$ \\
\hline $\begin{array}{l}1.2 .2 .1 .3 .2 \\
\text { Ion extractor }\end{array}$ & $\begin{array}{l}\text { Failure of } \\
\text { graphite } \\
\text { component or } \\
\text { coating }\end{array}$ & $\begin{array}{l}\text { Detreased } \\
\text { module capacity } \\
\text { or premature } \\
\text { module shutdown. }\end{array}$ & n. & VL & 㥩 & $\begin{array}{l}\text { Component or coating failure } \\
\text { before avg, run time is reached } \\
\text { is highiy inprobable. coating de- } \\
\text { qradat ign after avg. runtime is } \\
\text { reached is anticyated and is } \\
\text { accounted for by pod } \\
\text { refurbishnent. }\end{array}$ \\
\hline
\end{tabular}

w 
Table 4-6. (Cont inued)

\begin{tabular}{|c|c|c|c|c|c|c|}
\hline $\begin{array}{l}\text { WOS No. } \\
\text { item nane }\end{array}$ & $\begin{array}{l}\text { Potential } \\
\text { failure }\end{array}$ & $\begin{array}{l}\text { Failure } \\
\text { effect }\end{array}$ & $\begin{array}{l}\text { seauence } \\
\text { faflure } \\
M, \text { I) }\end{array}$ & $\begin{array}{l}\text { Probabllity } \\
\text { of Fallure } \\
\left(\mathrm{H}, \mathrm{M}_{0}, \mathrm{~L}\right)\end{array}$ & $\begin{array}{l}\text { Special } \\
\text { action } \\
\text { reauirad } \\
\text { (yes/no) }\end{array}$ & Comments \\
\hline & $\begin{array}{l}\text { Cormponent falls } \\
\text { into meit }\end{array}$ & $(\sec 1.2 .2 .1 .3 .1)$ & I & n & no & (see 1.2 .2 .1 .3 .1 ) \\
\hline \multirow[t]{3}{*}{$\begin{array}{l}\text { 1.2.2.1.3.3 } \\
\text { withdrawal system }\end{array}$} & $\begin{array}{l}\text { Casting accu- } \\
\text { nulator struc- } \\
\text { tural foilure }\end{array}$ & $\begin{array}{l}\text { Loss of } \\
\text { vacuum }\end{array}$ & 5 & L & Pes & $\begin{array}{l}\text { Module turniround time mould be } \\
\text { increused due to unscheduled } \\
\text { eleanup. }\end{array}$ \\
\hline & 0-ring failure & $\begin{array}{l}\text { Loss of } \\
\text { vaculum }\end{array}$ & I & b & Ho & 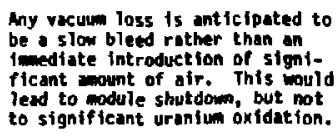 \\
\hline & Heater fallure & $\begin{array}{l}\text { Uranium } \\
\text { freeze in } \\
\text { withdrawal } \\
\text { overflow, } \\
\text { module shut- } \\
\text { down. }\end{array}$ & 1 & $m$ & to & $\begin{array}{l}\text { Loss of one heater ean generally } \\
\text { be tolerated with no effect on } \\
\text { performance. }\end{array}$ \\
\hline Aignivent system & $\begin{array}{l}\text { System fails } \\
\text { completely or } \\
\text { functions at a } \\
\text { less than } \\
\text { optimal level }\end{array}$ & $\begin{array}{l}\text { Decreased } \\
\text { module } \\
\text { capacity or } \\
\text { premature } \\
\text { module shutdown }\end{array}$ & 1 & $M$ & No & $\begin{array}{l}\text { The al ignont system generally } \\
\text { isn't reauired after the system } \\
\text { temperatures have equilibrated }\end{array}$ \\
\hline \multirow[t]{3}{*}{$\begin{array}{l}1.2 .2 .1 \cdot 3.5 \\
\text { Thermal system }\end{array}$} & $\begin{array}{l}\text { Systen fai is } \\
\text { or operates }\end{array}$ & $\begin{array}{l}\text { Loss of liquidd } \\
\text { Plow, loss of }\end{array}$ & I & M & in & $\begin{array}{l}\text { Shutdown module and carryout } \\
\text { nomal pod replacement. }\end{array}$ \\
\hline & incorrectly & $\begin{array}{l}\text { pod production } \\
\text { potentlal loss } \\
\text { of module } \\
\text { production }\end{array}$ & & & & \\
\hline & $\begin{array}{l}\text { Cooling shroud } \\
\text { loss of water } \\
\text { containment }\end{array}$ & $\begin{array}{l}\text { Introduction } \\
\text { of cooling } \\
\text { water into } \\
\text { module, loss } \\
\text { of vacuum, loss } \\
\text { of production }\end{array}$ & 1 & $\mathbf{L}$ & No & $\begin{array}{l}\text { Extended module downt ime due to } \\
\text { long cleanup. }\end{array}$ \\
\hline
\end{tabular}

a) 1000 hour design 1ife. 
Table 4-7. Preliminary Risk Assessment for HBS 1.2.2.3 Module System.

\begin{tabular}{|c|c|c|c|c|c|c|}
\hline $\begin{array}{l}\text { WBS No. } \\
\text { item name }\end{array}$ & $\begin{array}{l}\text { Potential } \\
\text { failure }\end{array}$ & $\begin{array}{l}\text { Failure } \\
\text { effect }\end{array}$ & $\begin{array}{l}\text { Consequence } \\
\text { of } f \text { ailure } \\
(S, M, I)\end{array}$ & $\begin{array}{l}\text { Probability } \\
\text { of failure } \\
(H, H, L)\end{array}$ & $\begin{array}{l}\text { Special } \\
\text { action } \\
\text { required } \\
\text { (yes/no) }\end{array}$ & Coments \\
\hline \multirow[t]{2}{*}{$\begin{array}{l}1.2 .2 .3 .7 .1 \\
\text { Process vessel }\end{array}$} & $\begin{array}{l}\text { Rapid loss } \\
\text { of yacuutem }\end{array}$ & $\begin{array}{l}\text { Repid oxidation } \\
\text { of U metal }\end{array}$ & n & $\mathbf{L}$ & so & Shutdown module and repatr. \\
\hline & $\begin{array}{l}\text { Thernal l liner } \\
\text { panels leak or } \\
\text { don't f low } \\
\text { coolant }\end{array}$ & $\begin{array}{l}\text { Cool ing water } \\
\text { introduced } \\
\text { into vesse1. } \\
\text { Vessel is } \\
\text { not cooled }\end{array}$ & I & . & No & $\begin{array}{l}\text { System shuts dow to safe } \\
\text { conf } 1 \text { guration. }\end{array}$ \\
\hline $\begin{array}{l}\text { 1.2.2.3.1.2 } \\
\text { Partition panels }\end{array}$ & $\begin{array}{l}\text { Pane1s leak } \\
\text { ar don't } \\
\text { flow coolant }\end{array}$ & $\begin{array}{l}\text { Cooling water } \\
\text { introduced } \\
\text { into vesset. } \\
\text { Vessel is } \\
\text { not cooled }\end{array}$ & 1 & $L$ & No & $\begin{array}{l}\text { System shuts down to safe } \\
\text { conf iguration. }\end{array}$ \\
\hline $\begin{array}{l}\text { Rail } \\
\text { Rysten }\end{array}$ & $\begin{array}{l}\text { Oifficulty or } \\
\text { lnability to } \\
\text { remove pod } \\
\text { with nomal } \\
\text { means }\end{array}$ & $\begin{array}{l}\text { Alternate } \\
\text { method must } \\
\text { be used to } \\
\text { remove pod }\end{array}$ & $M$ & $L$ & No & $\begin{array}{l}\text { on alternate method can be used } \\
\text { to remove the pods and get the } \\
\text { module back on lint. }\end{array}$ \\
\hline $\begin{array}{l}\text { 1.2.2.3.7.4 } \\
\text { Magnetic field colls }\end{array}$ & $\begin{array}{l}\text { colls cease } \\
\text { operat ion or } \\
\text { or operate } \\
\text { incorrect iy }\end{array}$ & $\begin{array}{l}\text { Premature } \\
\text { vessel shut- } \\
\text { down }\end{array}$ & $\mathbf{I}$ & $\mathbf{L}$ & Ho & $\begin{array}{l}\text { Continuous monitoring of magnetic } \\
\text { field ccils is provided to ensure } \\
\text { proper E-beam contalmment. }\end{array}$ \\
\hline $\begin{array}{l}\text { 1.2.2.3.3.1 } \\
\text { Mechanical vacuem } \\
\text { pumps }\end{array}$ & $\begin{array}{l}\text { Pump fails or } \\
\text { aperates } \\
\text { poorly }\end{array}$ & $\begin{array}{l}\text { Increased } \\
\text { module turn- } \\
\text { around time or } \\
\text { module shutdown } \\
\text { until pump is } \\
\text { repaired. }\end{array}$ & n & 1 & No & $\begin{array}{l}\text { Redundant pumping capacity is } \\
\text { provided. }\end{array}$ \\
\hline $\begin{array}{l}\text { 1.2.2.3.3.3 } \\
\text { Diffusion vacuum } \\
\text { Dumps }\end{array}$ & $\begin{array}{l}\text { Pump fails or } \\
\text { operotes } \\
\text { poorly }\end{array}$ & $\begin{array}{l}\text { Increased } \\
\text { module } \\
\text { punp down- } \\
\text { time }\end{array}$ & $I$ & $\downarrow$ & Ho & $\begin{array}{l}\text { Loss of one diffusion vacuum } \\
\text { pump will mot cause a loss in } \\
\text { production. }\end{array}$ \\
\hline
\end{tabular}


Table 4-7. (Continued)

\begin{tabular}{|c|c|c|c|c|c|c|}
\hline $\begin{array}{l}\text { HBS No. } \\
\text { item nome }\end{array}$ & $\begin{array}{l}\text { Potential } \\
\text { failure }\end{array}$ & $\begin{array}{l}\text { Faflure } \\
\text { effect }\end{array}$ & $\begin{array}{l}\text { Conseguence } \\
\text { of f f ilure } \\
(\mathrm{S}, \mathrm{m}, \mathrm{I})\end{array}$ & $\begin{array}{l}\text { Probability } \\
\text { of faflure } \\
(\mathrm{H}, \mathrm{H}, \mathrm{L})\end{array}$ & $\begin{array}{l}\text { Spectial } \\
\text { action } \\
\text { required } \\
\text { (yes/no) }\end{array}$ & Coments \\
\hline $\begin{array}{l}\text { 1.2.2.3.4.1 } \\
\text { Fan/filter Units }\end{array}$ & $\begin{array}{l}\text { Failure of } \\
\text { units }\end{array}$ & $\begin{array}{l}\text { Alternate } \\
\text { means of } \\
\text { manned entry } \\
\text { to module } \\
\text { would be } \\
\text { required. } \\
\text { Manned entry } \\
\text { could be made } \\
\text { ilth proper } \\
\text { respiratory } \\
\text { protect lon }\end{array}$ & 1 & $L$ & No & $\begin{array}{l}\text { Manned entry is not planned as } \\
\text { part of normal operations. } \\
\text { Redundancy is provided. }\end{array}$ \\
\hline $\begin{array}{l}1.2 .2 .3 .4 .2 \\
\text { Duct Work }\end{array}$ & $\begin{array}{l}\text { Breach of } \\
\text { duct work }\end{array}$ & $\begin{array}{l}\text { Snall amounts } \\
\text { of contamina- } \\
\text { tion spread } \\
\text { at the breach }\end{array}$ & 1 & $\mathbf{L}$ & no & $\begin{array}{l}\text { Breach would be setected, con- } \\
\text { twination cleaned up. opera- } \\
\text { tions of wodule would not be } \\
\text { affected. Redundency is provided. }\end{array}$ \\
\hline
\end{tabular}


Table 4-8. Preliminary Risk Assessment for HBS 1.2.2.4 Refurb15hment/Test.

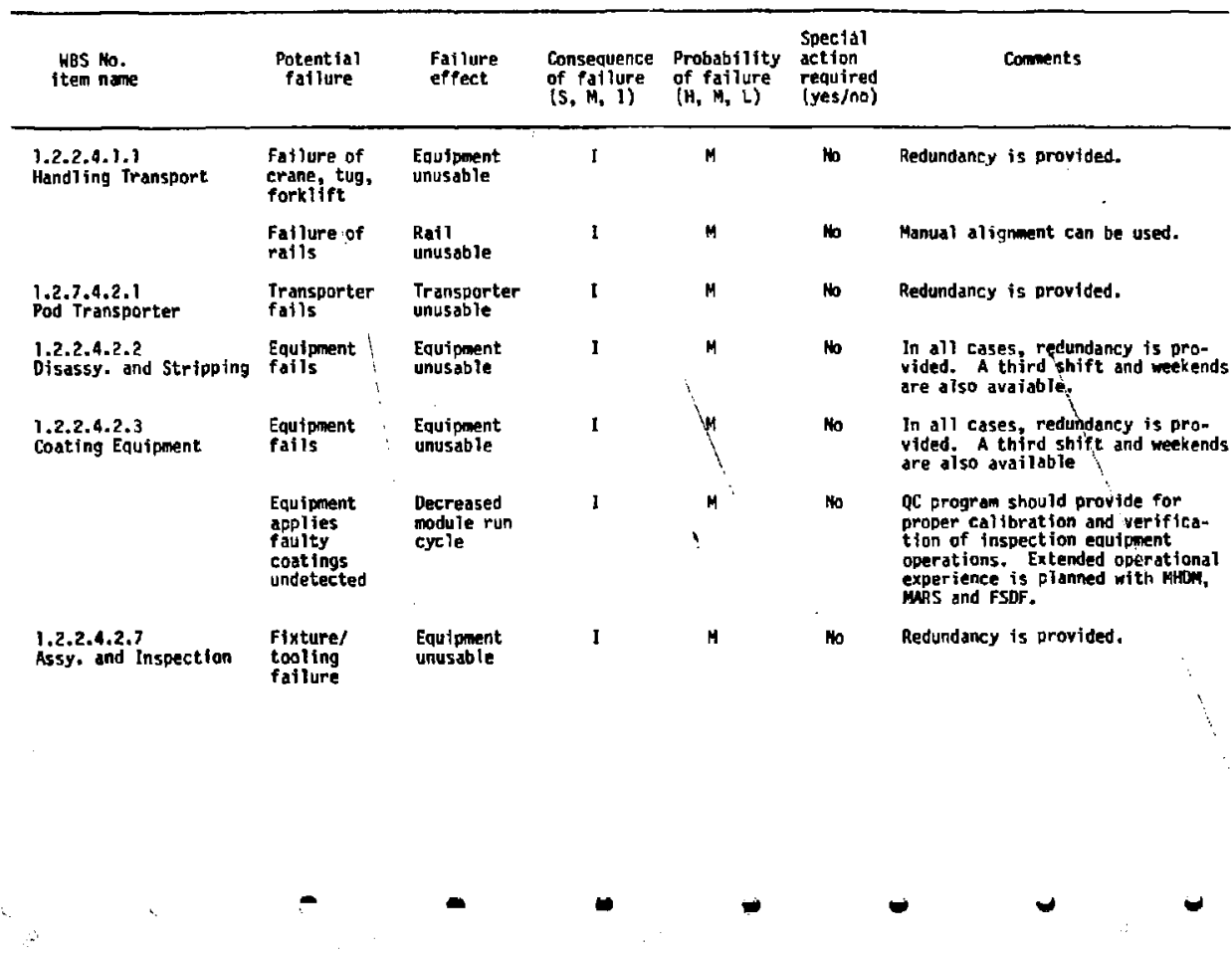


Tabie 4-8. (Cont inued)

\begin{tabular}{|c|c|c|c|c|c|c|c|}
\hline NBS ho. & & $\begin{array}{l}\text { Potential } \\
\text { faflure }\end{array}$ & $\begin{array}{l}\text { Fallure } \\
\text { effect }\end{array}$ & $\begin{array}{l}\text { Consequence } \\
\text { of failure } \\
(\mathrm{S}, \mathrm{M}, \mathrm{I})\end{array}$ & $\begin{array}{l}\text { Probabilitty } \\
\text { of failure } \\
(H, M, L)\end{array}$ & $\begin{array}{l}\text { Special } \\
\text { action } \\
\text { required } \\
\text { (yes/no) }\end{array}$ & Comments \\
\hline \multirow{2}{*}{\multicolumn{2}{|c|}{$\begin{array}{l}\text { 1.2.2,4.2.5 } \\
\text { Eiectrical comp. } \\
\text { Refurbishment }\end{array}$}} & $\begin{array}{l}\text { Equipment } \\
\text { fails }\end{array}$ & $\begin{array}{l}\text { Equipment } \\
\text { unusable }\end{array}$ & $I$ & $M$ & No & Redundancy is provided. \\
\hline & & $\begin{array}{l}\text { Equipment } \\
\text { provides } \\
\text { fatily } \\
\text { readings }\end{array}$ & $\begin{array}{l}\text { Pod is } \\
\text { incorrectly } \\
\text { certified, } \\
\text { decreased } \\
\text { run time }\end{array}$ & $\mathrm{I}$ & $\mathbf{M}$ & Ho & $\begin{array}{l}\text { OC progra should provide for } \\
\text { proper calibratian and verlfica- } \\
\text { tion of electrical component } \\
\text { refuro. equipment operation. }\end{array}$ \\
\hline $\begin{array}{l}1.2 . .2 .4 .2 .6 \\
\text { Mech. Comp. R }\end{array}$ & Refurb. & $\begin{array}{l}\text { Equipment } \\
\text { faijs }\end{array}$ & $\begin{array}{l}\text { Equiponent } \\
\text { unus bble }\end{array}$ & $\mathbf{I}$ & $\mathbf{H}$ & No & Redundancy is provided \\
\hline $\begin{array}{l}\text { 3.2.2.4.2.7 } \\
\text { Air Handiting }\end{array}$ & Systen & $\begin{array}{l}\text { Fan/f llter/ } \\
\text { duct work } \\
\text { falls }\end{array}$ & $\begin{array}{l}\text { Loss of } \\
\text { contamination } \\
\text { control in } \\
\text { refurb, area, } \\
\text { localized } \\
\text { contiantaation }\end{array}$ & I & $\mathbf{L}$ & No & $\begin{array}{l}\text { This system w1ll be protected to } \\
\text { prevent a loss of entire system } \\
\text { which could effectively shutdown } \\
\text { the refurb. area. Short term } \\
\text { shutdows of the system should not } \\
\text { signif icantly affect refurbishment } \\
\text { operations. Redundancy is } \\
\text { provided. }\end{array}$ \\
\hline 1.2 .2 .4 .3 .1 & Tooling & $\begin{array}{l}\text { Tooling } \\
\text { failure }\end{array}$ & $\begin{array}{l}\text { Tool ing } \\
\text { unus able }\end{array}$ & $l$ & H & No & Redundancy is provided. \\
\hline \multirow[t]{2}{*}{1.2 .2 .4 .3 .2} & $\begin{array}{l}\text { Test } \\
\text { Equipantent }\end{array}$ & $\begin{array}{l}\text { Equipuent } \\
\text { fails }\end{array}$ & $\begin{array}{l}\text { Equipment } \\
\text { unusable }\end{array}$ & $\mathbf{1}$ & $\mathbf{M}$ & tho & Redundancy is provided. \\
\hline & & $\begin{array}{l}\text { Equipment } \\
\text { gives faulty } \\
\text { readings }\end{array}$ & $\begin{array}{l}\text { Decreased } \\
\text { madule run } \\
\text { time }\end{array}$ & $\mathbf{I}$ & M & No & $\begin{array}{l}\text { Equipment will be periodically } \\
\text { calibrated. }\end{array}$ \\
\hline
\end{tabular}


Table 4-9. Preliminary Risk Assessment for WBS 1.3.1 Feed Conversion.

\begin{tabular}{|c|c|c|c|c|c|c|}
\hline $\begin{array}{l}\text { uBS No. } \\
\text { ittem naine }\end{array}$ & $\begin{array}{l}\text { Potential } \\
\text { failure }\end{array}$ & $\begin{array}{l}\text { Failure } \\
\text { effect }\end{array}$ & $\begin{array}{l}\text { onsequence } \\
\text { if } f \text { atlure } \\
S, M, I)\end{array}$ & $\begin{array}{l}\text { Probability } \\
\text { of failure } \\
(\mathrm{H}, \mathrm{H}, \mathrm{L})\end{array}$ & $\begin{array}{l}\text { Special } \\
\text { action } \\
\text { required } \\
\text { (yes } / \text { no }\end{array}$ & Cownents \\
\hline \multirow[t]{3}{*}{$\begin{array}{l}1.3 .1 .1 \\
\mathrm{UF}_{4} \text { Production }\end{array}$} & $\begin{array}{l}\text { Leak of } \mathrm{H}_{2} \text { and } \\
\text { subsequent } \\
\text { explosion. }\end{array}$ & $\begin{array}{l}\text { Hazard to per- } \\
\text { sonnel. }\end{array}$ & 5 & $L$ & Yes & $\begin{array}{l}\text { Risk assessments to be performed } \\
\text { where leaks might occur. }\end{array}$ \\
\hline & $\begin{array}{l}\text { Airborne relesse } \\
\text { of UF and } \mathrm{HF} \\
\text { in reduction towers } \\
\text { andfor support } \\
\text { equipment }\end{array}$ & $\begin{array}{l}\text { Partial loss } \\
\text { of UF } 4 \text { tion } \\
\text { production } \\
\text { (406 loss } \\
\text { per process } \\
\text { train disabied) }\end{array}$ & I & M & in & $\begin{array}{l}\text { There are independent. UF } 4 \text { re- } \\
\text { duction i ines. Downt ine is } \\
\text { expected to be only a few doys } \\
\text { for } a \text { line out of service. }\end{array}$ \\
\hline & . & & & & & . \\
\hline Siag Processing & $\begin{array}{l}\text { Failure of process } \\
\text { equipment sup- } \\
\text { porting size } \\
\text { reduction opera- } \\
\text { tlons, dust control } \\
\text { system leakage }\end{array}$ & $\begin{array}{l}\text { Partial loss } \\
\text { of process } \\
\text { avatlability to } \\
\text { support uranium } \\
\text { recovery and } \\
\text { reaction vessel } \\
\text { lining opera- } \\
\text { tlons. }\end{array}$ & M & $\mathbf{L}$ & No & $\begin{array}{l}\text { Dountime is expected to be only } \\
\text { a feu days. One day slag surge } \\
\text { storage is provided. }\end{array}$ \\
\hline $\begin{array}{l}\text { 1.3.:.5 } \\
\text { HF REcovery }\end{array}$ & $\begin{array}{l}\text { Failure of HF } \\
\text { containent systen }\end{array}$ & $\begin{array}{l}\text { Airborne } \\
\text { release, } \\
\text { exposure of } \\
\text { personnel to } \\
\text { hazardous material }\end{array}$ & 5 & L & Yes & $\begin{array}{l}\text { Liquid if storage tanks are } \\
\text { Iocated out-of -doors to factlitate } \\
\text { air dilution if leakage securs. }\end{array}$ \\
\hline $\begin{array}{l}1.3 .1 .7 \\
\text { Hg Storage }\end{array}$ & $\begin{array}{l}\text { Spontaneous } \\
\text { combustion of } \mathrm{Mg}\end{array}$ & $\begin{array}{l}\text { Loss of } \mathrm{Hg} \\
\text { feed to support } \\
\text { derby production, } \\
\text { fire damage to } \\
\text { to facility }\end{array}$ & M & $\mathbf{L}$ & No & $\begin{array}{l}\text { my storaqe is compartmented } \\
\text { and fire resistant to linit loss } \\
\text { of ing feed. }\end{array}$ \\
\hline
\end{tabular}


Table 4-10. Preliminary Risk Assessment for HBS 1.3 .2 Feed Preparatín

\begin{tabular}{|c|c|c|c|c|c|c|}
\hline $\begin{array}{l}\text { WBS Ho. } \\
\text { item nome }\end{array}$ & $\begin{array}{l}\text { Potential } \\
\text { fat lure }\end{array}$ & $\begin{array}{l}\text { Fablure } \\
\text { effect }\end{array}$ & $\begin{array}{l}\text { Consequt } \\
\text { of failure } \\
(\mathrm{S}, \mathrm{M}, \mathrm{I})\end{array}$ & $\begin{array}{l}\text { robability } \\
\text { of failure } \\
(H, M, L)\end{array}$ & $\begin{array}{l}\text { Speciai } \\
\text { action } \\
\text { required } \\
\text { (yes/no) }\end{array}$ & Coniments \\
\hline \multirow[t]{2}{*}{$\begin{array}{l}\text { l.3.2.3 } \\
\text { Melting and } \\
\text { Casting }\end{array}$} & $\begin{array}{l}\text { Failure of } \\
\text { melting/casting } \\
\text { mehine, conveyor } \\
\text { crucible, and/or } \\
\text { comonents: pos- } \\
\text { sible molten } \\
\text { uranium eetal } \\
\text { fire hazard }\end{array}$ & $\begin{array}{l}\text { Partial loss of } \\
\text { production of } \\
\text { uranium alloy } \\
\text { feed materinis. } \\
\text { equipment dimage }\end{array}$ & L & M & No & $\begin{array}{l}\text { There are independent process } \\
\text { lines. Downtion is expected to } \\
\text { be oniy a few days. Operaeting } \\
\text { schedule can be expanded to } \\
\text { compensate for loss of eapacity. }\end{array}$ \\
\hline & $\begin{array}{l}\text { Mecidental } \\
\text { discharge of } \\
\text { molten uranium } \\
\text { feed material }\end{array}$ & $\begin{array}{l}\text { Personnel } \\
\text { injury, equip- } \\
\text { ment damage }\end{array}$ & $\mathbf{M}$ & $\mathbf{L}$ & No & \\
\hline
\end{tabular}


Table 4-11. Preliminary Risk Assessment for HeS 1.3.3 Product Conversion.

\begin{tabular}{|c|c|c|c|c|c|c|}
\hline $\begin{array}{l}\text { HBS No. } \\
\text { item name }\end{array}$ & $\begin{array}{l}\text { Potential } \\
\text { failure }\end{array}$ & $\begin{array}{l}\text { Failure } \\
\text { effect }\end{array}$ & $\begin{array}{l}\text { Canseauence } \\
\text { of failure } \\
(\mathrm{S}, \mathrm{M}, \mathrm{I})\end{array}$ & $\begin{array}{l}\text { Probability } \\
\text { of failure } \\
(\mathrm{H}, \mathrm{H}, \mathrm{L})\end{array}$ & $\begin{array}{l}\text { Special } \\
\text { action } \\
\text { required } \\
\text { (yes/no) }\end{array}$ & Comments. \\
\hline $\begin{array}{l}\text { 1.3.3. } \\
\text { Product } \\
\text { Conversion }\end{array}$ & & $\begin{array}{l}\text { Criticality } \\
\text { accident-possible } \\
\text { personnel injury }\end{array}$ & $s$ & L & Yes & $\begin{array}{l}\text { Criticality accident from } \\
\text { enriched product handing is } \\
\text { d generic concern throughout } \\
\text { the product conversion facility. } \\
\text { Extensive des ign reviews required. }\end{array}$ \\
\hline $\begin{array}{l}\text { l.3.3.1 } \\
\text { size Peduction }\end{array}$ & $\begin{array}{l}\text { Accident to and } \\
\text { ar fallure of the } \\
\text { size reduction } \\
\text { eauipment. }\end{array}$ & $\begin{array}{l}\text { Partlal loss of } \\
\text { grocess capacity } \\
\text { to support pro- } \\
\text { duct production, } \\
\text { to support pro- } \\
\text { uranium metal } \\
\text { oxidation }\end{array}$ & $I$ & $H$ & 160 & $\begin{array}{l}\text { Jaw crushers and roller mills } \\
\text { have } 1006 \text { spares. }\end{array}$ \\
\hline $\begin{array}{l}\text { 1.3.3.2 } \\
\text { Oxidation }\end{array}$ & $\begin{array}{l}\text { Faflure of vi- } \\
\text { brating tray } \\
\text { ktin and oxida- } \\
\text { tion equipment }\end{array}$ & $\begin{array}{l}\text { Partial loss of } \\
\text { process capacity } \\
\text { to } \$ \text { upoort pro- } \\
\text { duce production }\end{array}$ & 1 & $M$ & no & $\begin{array}{l}\text { Independent oxidation kilns are } \\
\text { provided. }\end{array}$ \\
\hline $\begin{array}{l}1.3 .3 .3 \\
\text { Fiuorination }\end{array}$ & $\begin{array}{l}\text { Fallure of } \\
\text { fluorination } \\
\text { reactor }\end{array}$ & $\begin{array}{l}\text { Airborn releases } \\
\text { to worktng area } \\
\text { partial loss of } \\
\text { process capacity } \\
\text { to support pro- } \\
\text { duct production } \\
\text { personnel injury } \\
\text { from exposure to } \\
\text { hazardous material }\end{array}$ & 1 & $M$ & Yes & $\begin{array}{l}\text { Potential exposure of personnel } \\
\text { to } \mathrm{F}_{2}, \mathrm{UF}_{6} \text { and } \mathrm{HF} \text {. }\end{array}$ \\
\hline
\end{tabular}


Table 4-11. (Cont inued)

\begin{tabular}{|c|c|c|c|c|c|c|}
\hline $\begin{array}{l}\text { MBS Mo. } \\
\text { itew nane }\end{array}$ & $\begin{array}{l}\text { Potentisi } \\
\text { failure }\end{array}$ & $\begin{array}{l}\text { Fallure } \\
\text { effect }\end{array}$ & $\begin{array}{l}\text { Consequence } \\
\text { of fallure } \\
(3, \mathrm{M}, \mathrm{I})\end{array}$ & $\begin{array}{l}\text { Probability } \\
\text { of failure } \\
(\mathrm{H}, \mathrm{M}, \mathrm{L})\end{array}$ & $\begin{array}{l}\text { Special } \\
\text { action } \\
\text { required } \\
\text { (yes/no) }\end{array}$ & Comments \\
\hline \multirow[t]{2}{*}{$\begin{array}{l}\text { 1.3.3.4 } \\
\text { uf } 6 \text { Purification }\end{array}$} & $\begin{array}{l}\text { Conteinment } \\
\text { failure of Uf } \\
\text { cold traps andor } \\
\text { distillation } \\
\text { colurius uurifica- } \\
\text { tion equipment }\end{array}$ & $\begin{array}{l}\text { Airbarne releases } \\
\text { to wark ing area, } \\
\text { partial loss of } \\
\text { process capacity } \\
\text { wu jupport pro." } \\
\text { duct production, } \\
\text { personnel injury } \\
\text { irom exposure to } \\
\text { hazardous material }\end{array}$ & I & L & W & $\begin{array}{l}\text { Large number of cold traps } \\
\text { aitigates the consegeences } \\
\text { in production caused by a } \\
\text { single trap failure }\end{array}$ \\
\hline & $\begin{array}{l}\text { Containment or } \\
\text { hardware fallure } \\
\text { of KOH Scrubber } \\
\text { equipment: }\end{array}$ & $\begin{array}{l}\text { F2, HF discharge } \\
\text { to environient }\end{array}$ & $M$ & $\mathbf{L}$ & to & $\begin{array}{l}\text { Monitored, eleuated release } \\
\text { mitigates release to environ- } \\
\text { aent. }\end{array}$ \\
\hline $\begin{array}{l}1.3 .3 .5 \\
\text { Blending }\end{array}$ & $\begin{array}{l}\text { Conteinment } \\
\text { faflure of } \\
\text { blending } \\
\text { equipment. }\end{array}$ & $\begin{array}{l}\text { Airborne releoses } \\
\text { to working area, } \\
\text { partfal loss of } \\
\text { process capacity } \\
\text { to support pro- } \\
\text { duct production, } \\
\text { personnel injury } \\
\text { from exposure to } \\
\text { hazardous material }\end{array}$ & 1 & $\mathbf{L}$ & No & $\begin{array}{l}\text { Monitoring and quick isolation } \\
\text { ifinit the released quantitios. }\end{array}$ \\
\hline
\end{tabular}


Table 4-1: eliminary Risk Assessment for HBS 1.3.4 Uraniun Recovery.

\begin{tabular}{|c|c|c|c|c|c|c|}
\hline $\begin{array}{l}\text { w85 No, } \\
\text { item name }\end{array}$ & $\begin{array}{l}\text { Potential } \\
\text { failure } \\
.\end{array}$ & $\begin{array}{l}\text { Fallure } \\
\text { effect }\end{array}$ & $\begin{array}{l}\text { Consequence } \\
\text { of } f \text { ailure } \\
(\mathrm{S}, \mathrm{m}, \mathrm{t})\end{array}$ & $\begin{array}{l}\text { Probatillity } \\
\text { of faflure } \\
(\mathrm{H}, \mathrm{M}, \mathrm{L})\end{array}$ & $\begin{array}{l}\text { Speciol } \\
\text { action } \\
\text { required } \\
\text { (yes/no) }\end{array}$ & Coments \\
\hline \multirow[t]{2}{*}{$\begin{array}{l}\text { 1.3.4.1 } \\
\text { Grinding/0xidation }\end{array}$} & $\begin{array}{l}\text { Failure of pro- } \\
\text { cess equipment } \\
\text { dust control } \\
\text { equipment to } \\
\text { contain material }\end{array}$ & $\begin{array}{l}\text { Loss of } \\
\text { uranivim } \\
\text { recovery. }\end{array}$ & I & $M$ & no & $\begin{array}{l}\text { Loss of facllity does not directly } \\
\text { affect production. }\end{array}$ \\
\hline & $\begin{array}{l}\text { Urantum metal } \\
\text { (casting slag) } \\
\text { oxidation in } \\
\text { grinding equipment } \\
\end{array}$ & $\begin{array}{l}\text { Equipment } \\
\text { damage, part- } \\
\text { tal loss of } \\
\text { recovered } \\
\text { uranium to } \\
\text { uF } 6 \text { feed } \\
\text { factility. }\end{array}$ & $M$ & $L$ & to & $\begin{array}{l}\text { Clean-up required, loss in } \\
\text { production is minor }\end{array}$ \\
\hline $\begin{array}{l}\text { 1.3.4.2 } \\
\text { Fiuorination }\end{array}$ & $\begin{array}{l}\text { Failure of pro- } \\
\text { cess equipment to } \\
\text { contain } \mathrm{F}_{2} \\
\text { and } \mathrm{UF}_{6}\end{array}$ & $\begin{array}{l}\text { Airborne re- } \\
\text { leases to } \\
\text { 'worktng area, } \\
\text { personnel } \\
\text { injury due } \\
\text { to exposure to } \\
\text { hazardous } \\
\text { materials. }\end{array}$ & M & $M$ & Yes & $\begin{array}{l}\text { Potential exposure of personnel } \\
\text { to } \mathrm{UF}_{6}\end{array}$ \\
\hline \multirow[t]{2}{*}{$\begin{array}{l}\text { 1.3.4.3 } \\
\text { Cold Trapping }\end{array}$} & $\begin{array}{l}\text { Uf } f_{S} \text { discharge } \\
\text { to wark ing drea }\end{array}$ & $\begin{array}{l}\text { Personnel } \\
\text { injury due to } \\
\text { exposure to } \\
\text { hazardous } \\
\text { matertal. }\end{array}$ & $M$ & L & $\mathrm{Ho}$ & $\begin{array}{l}\text { Monitoring and alarn mitivate } \\
\text { health hazard. }\end{array}$ \\
\hline & $\begin{array}{l}\text { Containent or } \\
\text { hardhare fallure } \\
\text { of koh scrubber } \\
\text { eouipment }\end{array}$ & $\begin{array}{l}\text { Fa, HF dis- } \\
\text { chisge to } \\
\text { work ing area } \\
\text { and/or environ- } \\
\text { anent, personnel } \\
\text { injury. }\end{array}$ & 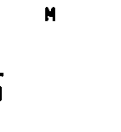 & $\mathbf{L}$ & No & $\begin{array}{l}\text { Wonitored, elevated release } \\
\text { mitigates risk to the envirorment. }\end{array}$ \\
\hline
\end{tabular}

के 
Table 4-13. Preliminary Risk Assessment for UBS 1.3.5. Process Suppart.

\begin{tabular}{|c|c|c|c|c|c|c|}
\hline $\begin{array}{l}\text { MaS Mo. } \\
\text { item nane }\end{array}$ & $\begin{array}{l}\text { Potential } \\
\text { failure }\end{array}$ & $\begin{array}{l}\text { Foilure } \\
\text { effect }\end{array}$ & $\begin{array}{l}\text { Consenuence } \\
\text { of fallure } \\
(S, M, 1)\end{array}$ & $\begin{array}{l}\text { Probability } \\
\text { of failure } \\
\langle H, M, L)\end{array}$ & $\begin{array}{l}\text { Special } \\
\text { action } \\
\text { required } \\
\text { (yes/no) }\end{array}$ & Coments \\
\hline $\begin{array}{l}\text { 1.3.5.3 } \\
\text { Flour ine Eeneration }\end{array}$ & $\begin{array}{l}\text { Containment or } \\
\text { hordware failure } \\
\text { of KOH Scrubher } \\
\text { equipment }\end{array}$ & $\begin{array}{l}F_{2,} \text { HF dis- } \\
\text { chiorge to } \\
\text { Norking area } \\
\text { andfor environ- } \\
\text { ment, personnel } \\
\text { injury. }\end{array}$ & 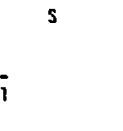 & $\mathbf{L}$ & Yes & $\begin{array}{l}\text { livillicored, elevated release } \\
\text { mitigates risk to the environment. }\end{array}$ \\
\hline
\end{tabular}




\section{PROGRAM IMPLEMENTATION AND CONTROL}

Both LLNL and Martin Marietta have in effect existing quality assurance programs and procedures that address engineering, procurement, construction, administration, and start-up operations for existing systems and facjlities. These quality assurance prograns further define and provide for the application of quality assurance action elements to the extent considered appropriate to the activities being performed, and they provide for the appropriate level of documentation to support the performance of these activities. The Quality Assurance Plan defined in this document will serve to continue to existing LLNL and Martin Marietta quality assurance programs when the project is initiated.

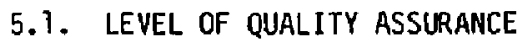

The level of quality assurance applied is based on the importance to health, safety, environmental protection, performance, reliability and project objectives. The level and extent of quality assurance is determined by the degree of concern identified in the risk assessment process. This quality assurance action approach is shown graphically in Fig. 5-1.

The Preliminary Risk Assessment in Sec. 4 of this document has identified systems of the AVLIS Production Plant that require special actions. Special actions are defined as those actions over and above the standard engineering, procurement, construction, operations practices, and industry codes and standards that must be implemented to assure performance arid project objectives. These special actions will be defined in detail in a Quality Assurance Action Plan. Action plans define the specific quality assurance steps to be taken during desigri, procurement, construction and start-up of the project. A more detailed risk assessment as wel? as the quality Assurance Action Plan will be prepared early in Titie 1 activities, based on this Plan and Preliminary Risk Assessment. This preliminary risk assessment shall be the basis for subsequent risk assessments and provides a basis for proceeding with conceptual design. 
C

C

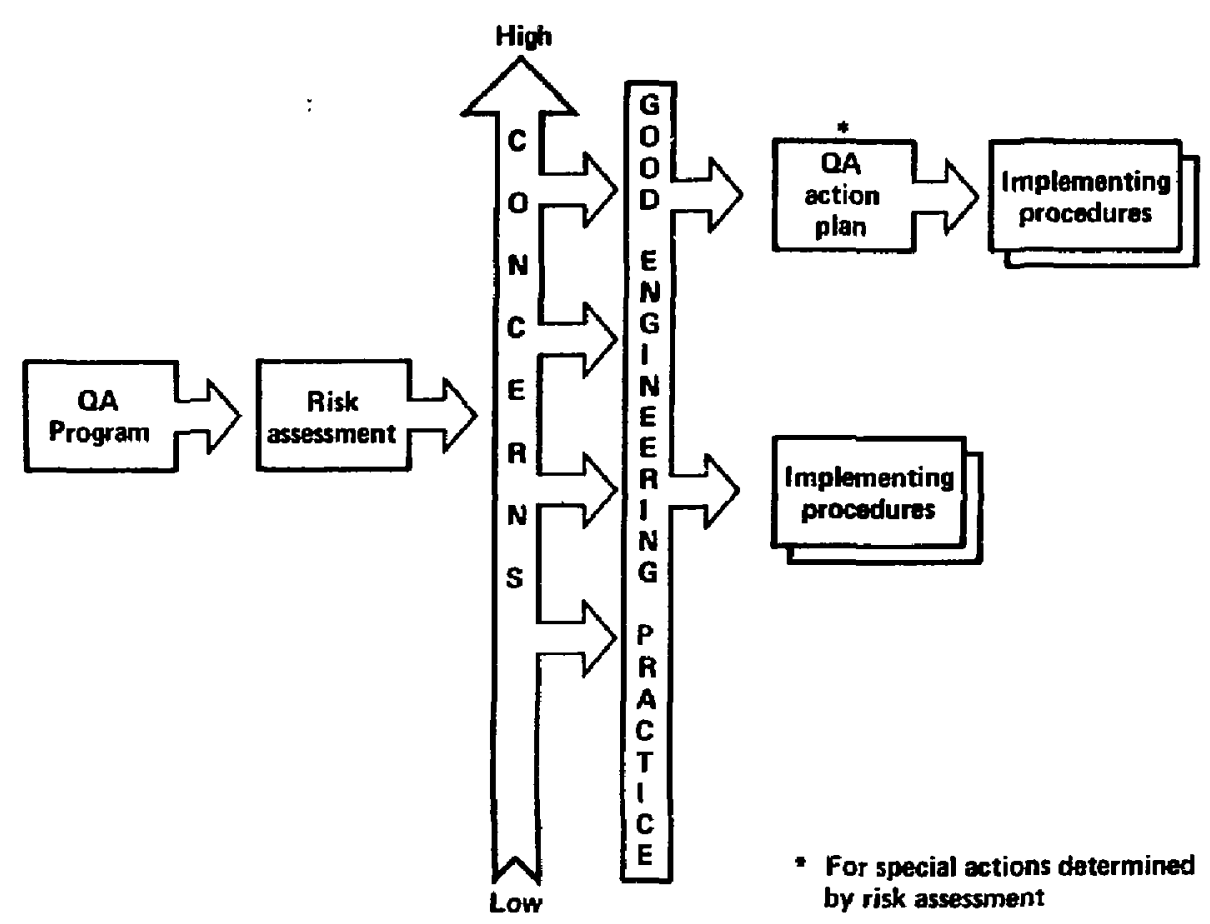

c

Fig. 5-1. Requirements of Quality Assurance Program. 
The special actions identified will be docunented and applied to design, procurement, and construction, utilizing the quality assurance action elements defined in Sec. 3. The selection of the appropriate Quality Assurance action elements is based on the risk assessment and quality assurance Action Plan. Engineering and management judgement assure the appropriate application of special actions for each item, system, service or facility.

Where no special actions are required, normal Quality Assurance practices will apply as will applicable industry codes and standards. Activities considered for control by standaró Quality Assurance practices include design and interface control, procurement control, construction control, document and records control, and Quality Assurance Program controls through appraisal and audits. In the next sections, the application of these practices are discussed in more detail.

\subsection{APPLICATION OF Quality Assurance ACTION ELEMENTS TO DESIGN}

Control of design activities during Title I \& II is defined in procedures that implement the quality Assurance Program. These procedures are listed in Table 5-1. Procedures for checking, review and approvals of drawings, calculations and specifications, design interface control and revision control are considered standard quality assurance practice in LLNL and MMES procedures. Special actions for design, when identified by risk assessment, will include the following: (1) design reviews and peer reviews not normally required, (2) inclusion of more stringent inspection and test requirements in drawings and specifications, (3) increased documentation requirements in specifications for yendors, and (4) supporting documentation for design activities. 
Table 5-1. Procedures Applicable to Design (Title I \& II).

\section{Design Control}

$c$

Design criteria control

Design interface control

Design calculation control

Computer calculation control

C

Drawing control

Specification control

Design reviews

Design document controi, review, and approval

E

Administration

Communication control

c

Records retention, control and turnover

Microfilming

Project Engineering

$\mathbf{c}$

Schedule control

Budget and cost control

Performance measurement system

C

Trends 


\subsection{APPLICATION OF Quality Assurance ACTION ELEMENTS TO PROCUREMENT}

Control of procurement activities is defined in procurement procedures that implement the Quality Assurance program. These precedures are listed in Table 5-2. Procedures for control of vendors through surveillance and shop inspection are considered standard quality assurance practice in LLNL and Martin Marietta procedures. Special actions for procurement, when identified by risk assessinent, will include (1) vendor qualification for special items or services, (2) increased vendor surveillance and shop inspection, (3) vendor submittal of a quality assurance program that responds to AVLIS Production Plant Quality Assurance Program, and (4) audits of vendor to assure compliance with Quality Assurance Program and specification requirements.

Tab7e 5-2. PROCEDURES APPLICABLE TO PROCUREMENT

Procurement document contro 1

Vendor qualification and surveys

Bid evaluation

Vendor evaluation

Vendor shop surveillance and inspection

vendor quality audits 


\subsection{APPLICATION OF Quality Assurance ACTION ELEMENTS TO CONSTRUCTION}

Control of construction activities is defined in construction quality control procedures that implement the Quality Assurance Progran. These procedures are 1isted in Table 5-3. Control of construction quality is considered standard Quality Assurance practice in LLN. and Martin Marietta procedures. Standard practices include routine inspection and verification of tests, material control, and routine weld control. Special actions for construction when identified by risk assessment will include (1) welder qualifications, (2) nondestructive testing and examination, (3) handling and

c. storage of special materials, (4) increased inspection, more stringent inspection and test requirements, and (5) increased documentation for inspection and test activities.

Tab7e 5-3. Procedures Applicable to Construction.

Vendor document review and approval

Weld control

Nondestructive examination

Qual if ication of personnel

Document controT

Material control

Measuring and test equipment calibration and control

Inspection

Test control

Records 


\subsection{QUALITY ASSURANCE PROGRAM SCHEDULE AND MILESTONES}

The Quality Assurance Program is initiated for the AVLIS Production Plant Project upon AVLIS process selections and continues through Title I. II, and III, and start-up phases of the project. The major milestones for the quality Assurance Program are listed in Table 5-4. The timing of Quality Assurance Key Milestones relative to the Authorization Limited Schedule is shown in Fig. 5-2.

\subsection{QUALITY AUDITS}

Quality audits are conducted to evaluate the effectiveness of a quality assurance activity and to verify compliance with the quality assurance activities. Quality audits serve as a mechanism for early detection of a breakdown in the implementation of the various systems established to assure quality. The audits shall be preplanned and scheduled in a manner to promote their effectiveness. Audits shall be conducted by appropriately trained and qualified personnel who have no direct responsibilities for the areas being audited. Results of audits shall be documented and reviewed by management.

\subsection{QUALITY FAILURE REPORTS}

When quality prcblems are encountered, each must be investigated to identify those corrective actions that will prevent a reoccurrence. Corrective actions consist of those actions required to fix the technical problems and of those actions required to prevent a reoccurrence. A quality failure reporting system shall be established such that all project participants can benefit from the identified corrective actions.

\subsection{QUAL ITY MANAGEMENT REPORTS}

There shall be established, a system for routinely informing management of the status of quality. Persons responsible for quality assurance programs shall regularly report to management on the effectiveness of the Quality 
Assurance program and on the status of any significant quality problems. This report will cover the status of quality assurance program implementation, procedures, audits, accomplishments, assessment status, action plan status, and status of corrective actions with schedules for completion.

C

$r$

C

(

$c$

C

C

C

c 
Table 5-4. Quality Assurance Program Milestones.

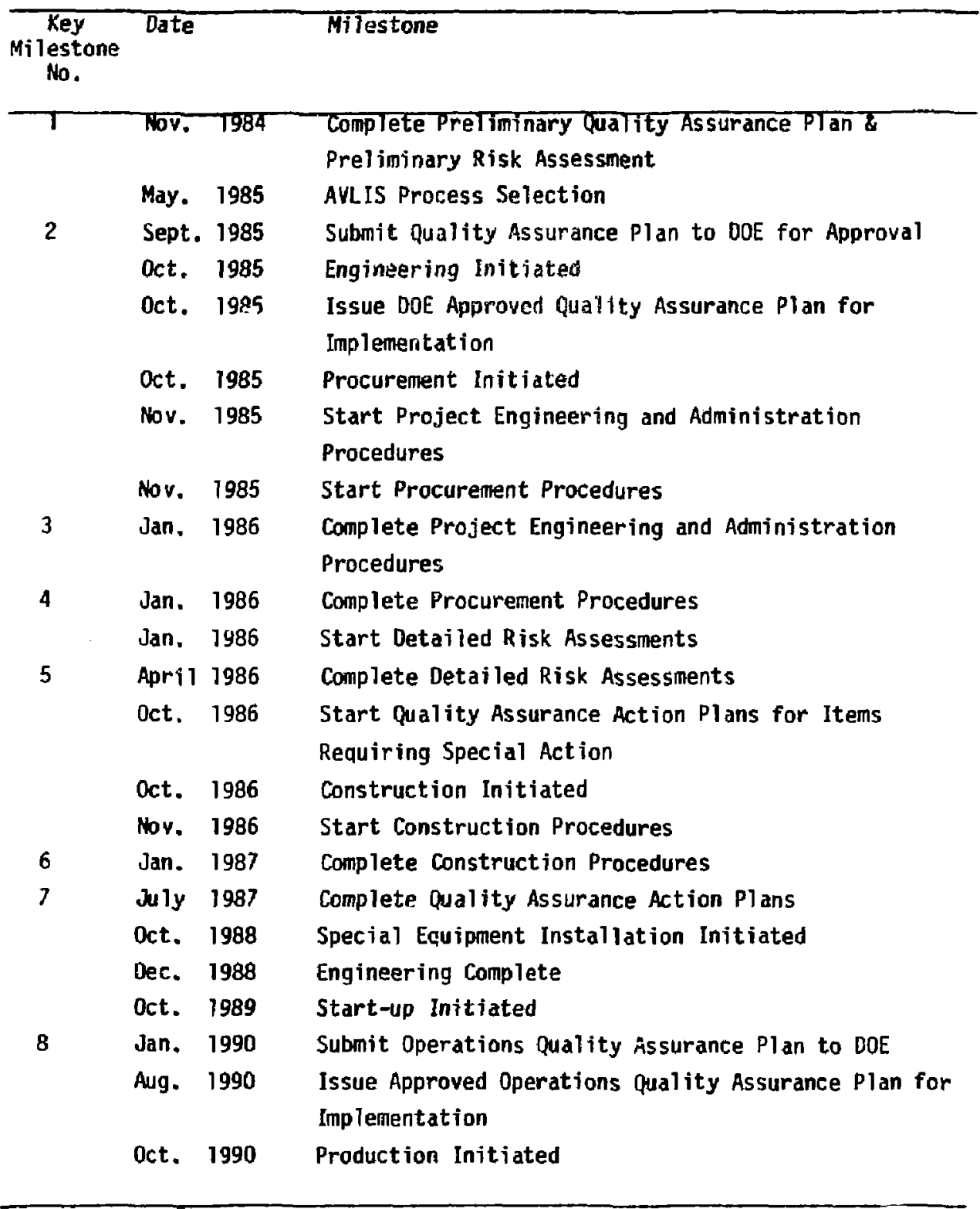




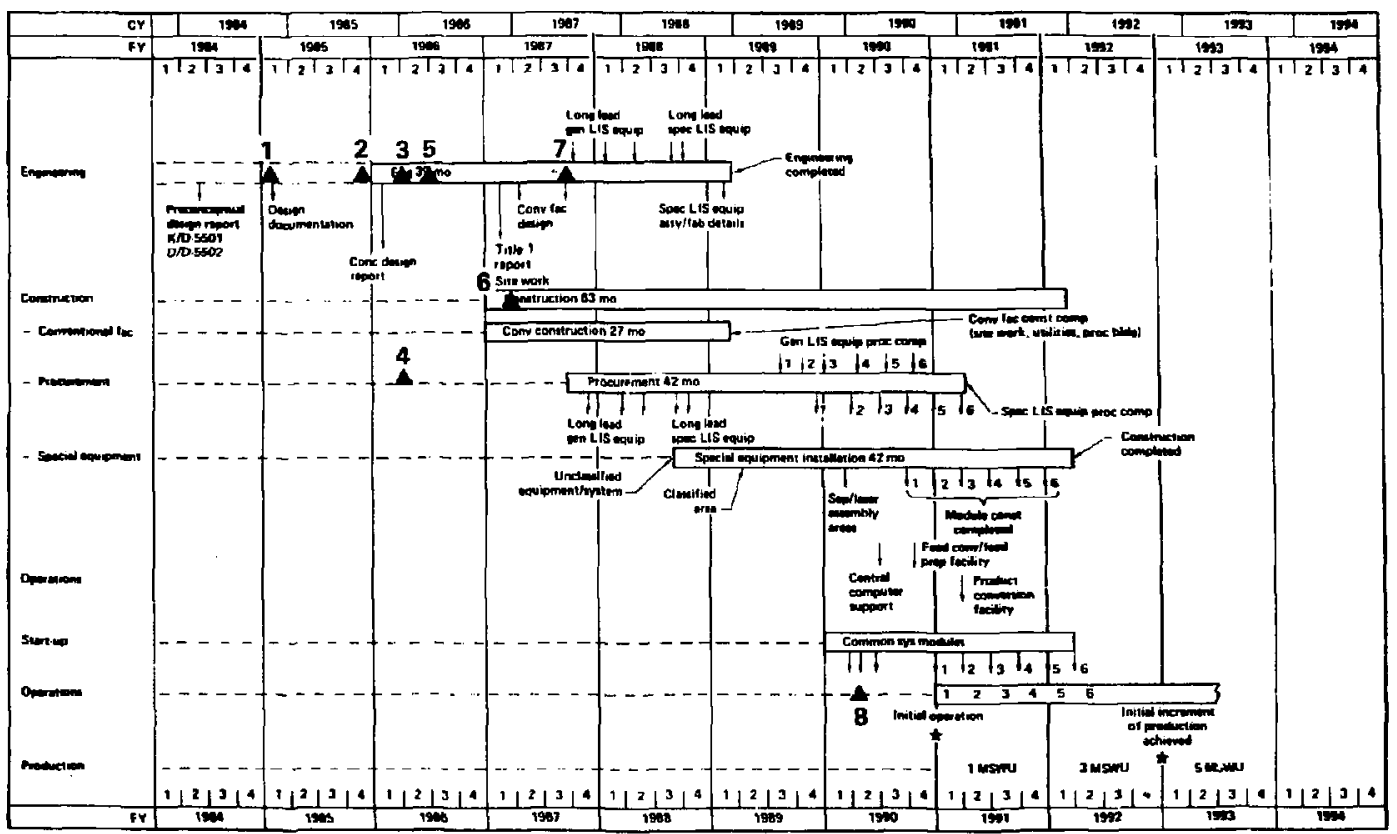

Fig. 5-2. Quality Assurance Program Key Milestones. See Table 5-4 for Milestone Definition and Mumber 
APPENOIX A

TLRHS AND DEFINITIONS

Acceptance Criteria: Specified limits placed on characteristics of an iten, process, or service defined in codes, standards, or other requirenent documents .

Audit: A planned and documented activity performed to determine by investigation, examination, or exaluation of objective evidence the adequacy of and compliance with established procedures, instructions, drawings, and other applicable documents, and the effectiveness of implementation.

Certificate of Compliance: A document signed by an authorized individual certifying the degree to which items or services meet specified requirements.

Certification: The act of determining, jerifying, and attesting in writing to the qualifications of personnel, processes, procedures, or items in accordance with specified requirements.

Characteristic: Any property or attribute of an item, process, or service that is distinct, describable, and measurable.

Condition Adverse to Quality: An all-inclusive term used in reference to any of the following: failures, malfunctions, deficiencies, defective items, and nonconformances. A significant condition adverse to quality is one which, if uncorrected, could have a serious effect on safety or operability.

Contractor: Any oraanization under contract for furnishing items or services. It includes the terms vendor, supplier, subcontractor, fabricator, and subtier levels of these where appropriate.

Corrective Action: Measures taken to rectify conditions adverse to quality and, where necessary, to preclude repetition.

Design Input: Those criteria, parameters, bases, or other design requirements upon which detailed final design is based.

Design 0utput: Documents, such as drawings, specifications, and other documents, defining technical requirements of structures, systems, and components.

Design Process: Technical and management processes that comence with identification of design input and that lead to and include the issuance of design output documents. 
Deviation: A departure from specified requirements.

Doctment: Any written or pictorial information óescribing, defining, specifying, reporting, or certifying activities, requirements, procedures, or results.

Final Design: Approves design output documents and approved changes

$\tau$ thereto.

Inspection: Examination or measurement to verify whether an item or activity conforms tú specified requirements.

Interface: The specificaliy defined physical and/or functional juncture

C between two or more itmes of equipment or between an item of equipment and facility.

Item: An all inclusive term used in place of any of the following: appurtenance, assembly, component, equipment, material, module, part, structure, subassembly, subsystem, system, or unit.

Measuring and Test Equipment (M\&TE): Devices or systems used to calibrate, measure, gage, iest, or inspect in order to control or to acquire data to verify conformance to specified requirements.

Nonconformance: A deficiency in characteristic, documentation, or procedure that renders the quality of an item or activity unacceptable or indeterminate.

Objective Evidence: Any documented statement of fact, other information, or record, either quantitative or qualitative, pertaining to the quality of an item or activity, based on observations, measurements, or test which can be verified.

Operator: The contractor responsible for operation of the plant.

Procedure: A document that specifies or describes how an activity is to be performed.

Procurement Document: Purchase requisitions, purchase orders, drawings, contracts, specifications, or instructions used to define requirements for purchase.

Purchaser: The organization responsible for establishment of procurement requirements and for issuance, administrations or both, of procurement documents. 
Qualification (Personnel): The characteristics or abilities gained through education, training, or experience, as measured against established requirements, such as standards or tests, that qualify an individual tc perform a required function.

Quality: Fitness for intended use.

Quality Assurance (QA): A11 those planned and systematic actions necessary to provide adequate confidence that an item or a facility will perform satisfactorily in service.

The goal of quality assurance is to assure that research, development, demonstration, and production activities are performed in a controlled manner; that components, systems, and processes are designed, developed, constructed, tested, operated, and miaintained according to sound engineering standards, quality practices, and technical specifications; and that resulting technology data are valid and retrievable. Quality assurance includes quality control, which comprises all tnose actions necessary to control and verify the features and characteristics of a material, process, product, or service to specified requirements.

Qualjty Assurance Action Plan (QAAP): A QAAP is a document which describes all the actions required to provide adequate assurance that items or services wili perform as specified.

Quality Control (QC): The prevention of defects through control of processing variables involving equipment, procedures, and personnel.

Quality Assurance Record: A completed document that furnishes evidence of the quality of items and/or activities affecting quality.

Receiving: Taking delivery of an item at a designated location.

Repair: The process of restoring a nonconforming characteristic to a condition such that the capability of an item to function reliably and safely is unimpaired, evel though that item still does not conform to the original requirement.

Ris': Assessment: A Risk As sessment is a formal qualitative review to determine the consequences and probability of failure of an item to perform as intended, and to identify items or activities requiring special actions. Risk Assessments shall be performed for all AVLIS systems, equipment, and structures defined in the Project Work Breakdown Structure. 
Routine Item: No special actions are required, however, appropriate steps are required to identify and prevent quality probiems. Nationally recognized codes and standards shall be invoked in specifications and drawings as applicable.

Service: The performance of activities such as design, fabrication,

c. inspection, nondestructive examination, repair, or installation.

Special Item: An item having a failure mode which can result in significant or unknown consequences in terms of production loss, equipment damage, schedule impact or personnel safety and health, with a : igh or unknown probability of occurrence. Special actions are required to eliminate or reduce the prabability of occurrence or to control the consequences of failure.

Surveillance: The act of monitoring or observing to verify whether an item or activity conforms to specified requirements.

C

Testing: An element of verification for the determination of the capability of an item to meet specified requirements by subjecting the item or activities by means of recorded identification.

Traceability: The ability to trace the history, application, or location of an item and like iteris or activities by means of recorded identification.

Verification: The act of reviewing, inspecting, testing, checking, auditing, or otherwise determining and documenting whether items, processes, services, or documents conform to specified requirements.

C

Waiver: Documented authorization to depart from specified requirenents. 


\section{INTERMAL MAIL}

$\begin{array}{ll}\text { J. I. Davis } & L-466 \\ \text { E. R. Ault } & L-463 \\ \text { M. H. Chew } & L-399 \\ \text { R. D. Dewitt } & L-372 \\ \text { J. H. Dubrin } & L-467 \\ \text { R. S. Hargrove } & L-467 \\ \text { J. G. Harri } & L-470 \\ \text { R. E. Hendrickson } & L-466 \\ \text { J. 2. Holtz } & L-459 \\ \text { J. A. Hortan } & L-470 \\ \text { E. I. Hoses } & L-462 \\ \text { R. H. O'Neil } & L-462 \\ \text { R. W. Patterson } & L-462 \\ \text { R. K. Robinson (5) } & L-438 \\ \text { M. L. Spaeth } & L-467 \\ \text { R. J. Tosetti (5) } & L-439 \\ \text { J. I. Davis } & \\ \text { CLYA Files (20) } & L-466 \\ \text { TID (15) } & L-658\end{array}$


C

Dr. Lester Ettlinger

The MITRE Corporation

METREK Division

1820 Dolley Madison Blvd.

c. McLean, VA 22102

Dr. James Rushton

Program and Process Planning

Martin Marietta Energy Systems

C

c

C

C

C

C

P. 0. Box P

Oak Ridge, TN 37831

Mr. Kenneth Sommerfeld

Vice Pres., Enrichment

Martin Marietta Energy Systems

P. 0. Box $P$

Oak Ridge, TN 37831

Mr. Richard Dierlam

U.S. Department of Energy

Advanced Technology Projects

Uranium Enrichment, NE-35

Office of Nuclear Energy

Washington, DC 20545

Mr. Don Erb

U.S. Department of Energy

Uranium Enrichment, NE-34

Office of Nuclear Energy

Washington, OC 20545

Process Evaluation Board

$\mathrm{c} / \mathrm{o} \mathrm{Dr}$. Kermit Laughon

PEB, Exec. Secretary

U.S. Department of Energy

Office of Nuclear Energy

Washington, D.C. 20545

Mr. Joseph W. Parks

U.S. Department of Energy

Oak $R$ idge Operations

P. O. Box E

Oak Ridge, TN 37830

H. M. Polansky

U.S. Department of Energy

Advanced Technology Projects

Urani um Enrichment, NE-35

Office of Nuclear Energy

Hashington, DC 20545
(3)

J. K. Hancock

(Project File for Congressional

(2)

Archives)

U.S. Department of Energy

Advanced Technology Projects

Urani um Enrichment , NE-35

Office of Nuclear Energy

Washington, DC 20545

J. R. Longenecker

U.S. Department of Energy

Office of Nuclear Energy

(10)

Washington, D.C. 20545

R. T. Ooten

U.S. Department of Energy

Oak Ridge Operations office

P. 0. Box E

Oak Ridge, TN 37830

J. Milloway

U.S. Department of Energy

Dak Ridge Operations Office

P. 0. Box E

Oak Ridge, TN 37830

D. F. Craig

M. 0. Dixon

C. E. Frye

R. L. Hoglund

A. L. Lotts

G. E. Michaels

(7)

J. S. Rayside

T. R. Smith

J. D. Stout

Martin Marietta Energy Systems

$(\mathrm{K}-25)$; P. 0. Box P

oak Ridge, TN 37830

U.S. Department of Energy

Technical Inf ormation Center

Dak Rídge, IN 37830 